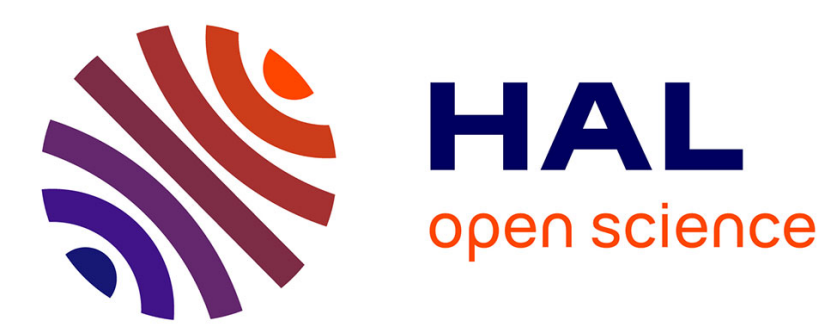

\title{
The Provision of Services, Interest Margins and Loan Pricing in European Banking
}

Laetitia Lepetit, Emmanuelle Nys, Philippe Rous, Amine Tarazi

\section{To cite this version:}

Laetitia Lepetit, Emmanuelle Nys, Philippe Rous, Amine Tarazi. The Provision of Services, Interest Margins and Loan Pricing in European Banking. 2006. hal-00918533

\section{HAL Id: hal-00918533 \\ https://hal-unilim.archives-ouvertes.fr/hal-00918533}

Preprint submitted on 13 Dec 2013

HAL is a multi-disciplinary open access archive for the deposit and dissemination of scientific research documents, whether they are published or not. The documents may come from teaching and research institutions in France or abroad, or from public or private research centers.
L'archive ouverte pluridisciplinaire HAL, est destinée au dépôt et à la diffusion de documents scientifiques de niveau recherche, publiés ou non, émanant des établissements d'enseignement et de recherche français ou étrangers, des laboratoires publics ou privés. 


\title{
The provision of services, interest margins and loan pricing in European banking
}

\author{
Laetitia Lepetit, Emmanuelle Nys, Philippe Rous, Amine Tarazi* \\ Université de Limoges, LAPE, 5 rue Félix Eboué, 87031 Limoges Cedex, France
}

December 2006

\begin{abstract}
This paper assesses the implications on bank interest margins of the expansion into nontraditional fee-based activities in European banking. We use a sample of 602 European commercial and cooperative banks from 1996 to 2002 and consider the total income shares of trading income and commission and fee income as measures of product diversification to explore loan pricing. Our results show that a higher income share from commission and fee activities is associated with lower margins and lower lending rates but that there is no link with trading activities. For banks exhibiting a higher share of commission and fee income there is a weaker link between the rate they charge on loans and borrower default risk. The hypothesis that banks use loans as a loss leader altering default screening and monitoring activities and consequently risk pricing cannot be rejected.
\end{abstract}

JEL classification: G21

Keywords: bank, interest income, non-interest income, interest margin, lending

\footnotetext{
*Corresponding authors: Tel: +33-555-14-92-13, emmanuelle.nys@unilim.fr (E. Nys); laetitia.lepetit@unilim.fr (L. Lepetit); philippe.rous@unilim.fr (P. Rous); amine.tarazi@unilim.fr (A. Tarazi).
} 


\section{Introduction}

With financial deregulation and the trend towards disintermediation European banks faced high competition in the 1990s. Commercial banks suffered from a sharp decline in interest margins and profitability on traditional intermediation activities which consist in transforming deposits into loans. Banks reacted to this new environment by diversifying into new activities which considerably altered their income structure by reducing the weight of their traditional lines of business. For instance, for commercial banks, the share of noninterest income in total income increased from 26\% to 41\% from 1989 to 1998 (ECB 2000). Most banking industries in western countries have experienced similar trends and in the case of the US the share of non-interest activities has grown from $19 \%$ in the 1980 s to $41 \%$ in 2001 (Stiroh, 2004). This new environment has several implications for the safety and the supervision of the banking system. First, it is not clear whether by widening the range of products they supply banks improve their risk/return trade off and their default risk. Second, the provision of a larger set of products increases the incentives of cross-subsidisation which may distort risk exposure. Consequently, among others, U.S. regulators, such as Dingell (2002), have raised questions about the pricing of loans and specifically the lending risk premium, claiming that "commercials banks may be winning high service fees by underpricing credit facilities as a loss leader to their clients".

There is an extensive literature that questions the implications of this new environment on bank risk but to our knowledge there has been no attempt to explore the link between product expansion and the pricing of traditional activities such as loans. A large strand of the literature dedicated to the expansion of banks' activities beyond deposit taking and lending, either focuses on portfolio diversification effects (risk return profile) (Boyd et al., 1980; Kwan, 1998; De Young and Roland, 2001) or on incentives approaches (Rajan, 1991; John et al., 1994; Puri, 1996; Boyd et al., 1998). Mostly based on U.S. data, the aim of these studies is to assess the overall effect on risk and only a few papers are able to show that the combination of lending and non-interest income activities allows for diversification benefits and therefore risk reduction. Conversely, some papers find a significant positive impact of diversification on earnings volatility (De Young and Roland, 2001; Stiroh, 2004; Stiroh and Rumble, 2006). Another strand of the literature which analyses the optimal behaviour of bank lending and interest margin setting (Klein, 1971; Monti, 1972; Ho and Saunders 1981) has integrated risk determinants as explanatory factors (Angbazo, 1997; Wong, 1997). These studies show how factors such as credit risk and interest risk affect bank interest margins. 
However, in this literature, to our knowledge, the issue of the expansion of banks towards non interest activities has never been raised. If banks actually use loans as a loss leader credit risk determinants of loan pricing should capture the presence of such effects and risk underpricing should in turn increase the overall bank default risk.

The aim of this paper is to revisit the bank interest margin literature to assess the impact on the lending rate of the expansion of financial intermediaries beyond traditional intermediation activities (deposit funded loans) and towards activities generating non-interest income. We use individual bank data from 1996 to 2002 for 602 European commercial and cooperative banks from 12 countries to estimate the determinants of loan rates and interest margins in a setting that accounts for the presence of non interest activities such as commission and fee activities and trading activities. Our measure of expansion towards non traditional activities is the net income share of non-interest income which is also split into the share of trading income and the share of commission and fee income. In order to explore whether banks engaged in product diversification actually underprice loans using them as a loss leader, we specifically focus on the determinants of loan rates.

This paper extends the earlier work on bank diversification and on bank interest margin and loan rate setting in several directions. First, this is one of the first studies dedicated to the issue of diversification that examine the case of the European banking industry which experienced tremendous changes over the last decade ${ }^{1}$. Second, this is the first paper which empirically raises the issue of loan pricing implications of the trend towards product diversification by assuming potentials for cross-selling among traditional and nontraditional activities which could induce banks to lower lending rates and underprice credit risk. Third, this is, to our knowledge, the first work which attempts to take into account the existence and the impact of non-interest activities in the bank interest margin framework.

The rest of the paper is laid out as follows. Section 2 presents the specification of our econometric model based on the interest margin literature and shows how our work extends

\footnotetext{
${ }^{1}$ Acharya, Hasan and Saunders (2002) have studied the case of Italian banks by looking at the degree of diversification of the loan portfolio. Their findings show that loan diversification is not guaranteed to produce a higher return and/or lower risk for banks. Another paper (Smith, Staikouras and Wood, 2003) dedicated to European banks focused on the correlation between non-interest income and interest income and their variability showing that the increased importance of non-interest income stabilised profits in the banking industry during the period 1994-1998. In a more recent study based on a broad panel of European listed banks, Baele et al. (2006) find that banks with higher levels of non interest income have higher expected returns but also higher systematic risk. Eventually, using a sample of European banks, Lepetit et al. (2006) show that the positive link between the share of non interest income and risk is mostly accurate for small banks and essentially driven by commission and fee activities. In their study, a higher share of trading activities is to some extent associated with lower asset and default risk for small banks.
} 
earlier studies. Section 3 presents the data and the results of our investigation of cross-selling between lending and non traditional activities. Section 4 concludes.

\section{Method and link with existing literature}

In this section we investigate the link between the pricing of loans (interest rate setting) and the shift towards non interest activities raising the issue of cross-selling of loans and fee-based activities. More precisely, our aim is to examine the hypothesis that banks have used traditional lending activities as a loss leader. Our assumption is that banks may require lower rates on their lending activities, underpricing credit risk which may in turn increase their overall risk level. Consequently, the price banks charge for loans should be a decreasing function of non-interest income and, particularly, commission and fee income. Specifically, granting a (long term) loan increases the probability of actually selling fee generating products to a core customer while the prospects of gaining from other non traditional activities, such as trading activities, remain unchanged. Therefore, we investigate the determinants of the lending rate by distinguishing commission and fee income and trading income.

We explore this issue by focusing on the determinants of the lending risk premium, i.e. the lending rate charged by the bank minus the risk free interest rate, using several definitions. Alternatively, we also consider the default spread that is the difference between the rate on a risky loan and the rate on a zero default bond of equivalent maturity. We use two different spread measures as proxies of the risk premium or the default spread: W_SPREAD which is the difference between the ratio of net interest income to total earning assets and either the 3 months or the 10 year government bond rate and N_SPREAD which is equal to the lending rate (determined as the ratio of interest from loans to net loans) minus either the 3 months or the 10 year government bond rate $^{2}$. For consistency with previous studies, we also consider the broader issue of bank interest margin setting with two measures of the net interest margin, frequently used in the bank interest margin literature (Ho and Saunders, 1981; Angbazo, 1997; Wong, 1997; Saunders and Schumacher, 2000), W_MARGIN which is the ratio of net interest income (defined as interest income minus interest expense) to total earning assets and N_MARGIN which is defined as the difference between the two following ratios: $i$ / the ratio

\footnotetext{
${ }^{2}$ Our results are not affected by the choice of a given maturity for the government bond. We focus on the 10 year rate by assuming that the average maturity (duration) of loans is close to 10 years. Nevertheless, we check for robustness using shorter maturities in our different estimations.
} 
of interest from loans to net loans and ii/ the ratio of interest expense to total liabilities (defined as total assets minus total equity).

Considering the optimal bank interest margin literature (Klein, 1971; Monti, 1972; Ho and Saunders, 1981; Angbazo, 1997; Wong, 1997; Saunders and Schumacher, 2000; Drakos, 2003; Maudos and Guevara, 2004), we first select a set of variables (see table 1) which are used in most studies aiming to capture the determinants of bank loan pricing to which we add product diversification variables. In line with previous papers (see Stiroh (2004)), the degree of diversification of bank activities is in our study given by the structure of income statements, that is the shares of net interest income generated by traditional activities and noninterest income produced by non traditional activities. We therefore define several variables. First, we consider the ratio of net non interest income to net operating income NNII. Net noninterest income is defined as the difference between non-interest income and non-interest expenses; net operating income is the sum of net interest income and net non interest income. Second, our product diversification measure is also disaggregated, as in De Young and Roland (2001) and in Stiroh (2004), to allow for deeper insights. More precisely, we distinguish two components of non-interest income: commission and fee income and trading income. We hence define a ratio of net commission and fee income to net operating income, $\mathrm{COM}$, and a ratio of net trading income to net operating income, TRAD. Net commission income is equal to commission income minus commission expense and net trading income is equal to trading income minus trading expense. Alternatively, we also define a variable, COMSHA, which measures the proportion of net commission and fee income in net non interest income.

\subsection{Model specification}

Four models are defined for each dependant variable. As a first step (equations [1] and [5] in table 1) we estimate the margin model and the spread model referring to a general specification often used in previous papers. For spread equations, the volatility (standard deviation) of the three months interbank rate (VR3M) measures uncertainty on the money market. Therefore, a higher risk premium should be required following a rise in interest rate volatility $\left(\beta_{2}>0\right)$. When dealing with margin equations, we substitute the level of the three months interbank rate $(\mathrm{R} 3 \mathrm{M})$ for its volatility $(\mathrm{VR} 3 \mathrm{M})$ : an increase in the level of the risk free rate implies a higher opportunity cost $\left(\alpha_{2}>0\right)$. The ratio of loan loss provisions to net loans (LLP) is considered as a measure of borrowers default risk for both margin and spread 
equations. A higher premium should be charged by banks to offset higher credit risk $\left(\alpha_{3}\right.$ and $\beta_{3}>0$ ). The ratio of equity to total assets (EQUITY) is often used in the literature as a proxy of the degree of bank risk aversion. Firms which are more risk averse may require a higher spread to cover the higher cost of equity financing compared to other sources of funding $\left(\alpha_{5}\right.$ and $\beta_{4}>0$ ). The variable TA_R, defined as the total assets for bank i divided by the sum of the total asset of the banking system, is introduced as a proxy of bank market power which is often associated with higher lending rates. Therefore, the expected sign of the coefficient is positive ( $\alpha_{6}$ and $\beta_{5}>0$ ). However, because of the "Too big to fail" effect, banks may prefer to decrease their risk premium $\left(\alpha_{6}\right.$ and $\left.\beta_{5}<0\right)$ in order to attract borrowers. Regarding personnel expenses (EXPENSES) the literature provides mixed results on the expected coefficient. Because screening and monitoring of borrowers require higher personnel costs, the default risk premium charged on loans can be lower $\left(\alpha_{7}\right.$ and $\left.\beta_{6}<0\right)$. Conversely, as the cost of granting loans increases with personnel expenses banks should charge a higher premium $\left(\alpha_{7}\right.$ and $\left.\beta_{6}>0\right)$. We also consider liquidity risk for margin equations measured as the ratio of net loans to deposits (LIQUIDITY). As the ratio increases, liquidity risk increases implying a higher margin set by banks $\left(\alpha_{4}>0\right)$.

\subsection{Hypothesis tests}

By augmenting several specifications of the standard model with diversification variables (see table 1, equations [2] to [4] for margin setting and equations [6] to [8] for spread determinants) our aim is to capture loan pricing implications of the degree of bank diversification and to check for the robustness of results. If banks which are more reliant on non interest activities reduce their lending rates, we expect a negative coefficient for the variable NNII which measures product diversification $\left(\alpha_{8}\right.$ and $\left.\beta_{7}<0\right)$ and for COMSHA, COM and TRAD which are proxies of the structure of diversification $\left(\alpha_{9}, \alpha_{10}, \alpha_{11}, \beta_{8}, \beta_{9}\right.$ and $\left.\beta_{10}<0\right)$.

Hypothesis 1: Banks more heavily engaged in non interest activities and particularly in commission and fee activities set a lower interest margin and/or charge a lower lending rate.

To further investigate this issue we also consider alternative specifications to test the extent to which credit risk is actually taken into account in loan interest rate setting. For this purpose, we estimate augmented models which capture the interaction of non interest generating activities and default risk (see table 1, equations [9] to [11] and equations [12] to 
[14]). More precisely, interacting variables are introduced to measure the impact of non interest generating activities on the borrower's default risk component of the lending rate and the interest margin $\left(\alpha_{12}, \alpha_{13}, \alpha_{14}, \alpha_{15}, \beta_{11}, \beta_{12}, \beta_{13}\right.$ and $\left.\beta_{14}<0\right)$. In other words, a negative coefficient implies that for a given level of borrower default risk banks charge a lower default risk premium when they are more diversified.

Hypothesis 2: Banks more engaged in non interest activities and particularly in commission and fee activities underprice credit risk.

One could argue that the inclusion of interaction terms in the equations is not the most accurate method to capture cross subsidy effects and specially distortion effects in credit risk pricing. Banks may actually charge lower interest rates on loans but, in return, collect higher fees from the same borrower to offset a higher exposure to default risk. In that case loan loss provisions based on earned interest no longer serve as a buffer against borrower default but banks can rely on other non-interest income to control their risk exposure. Nevertheless, if commission and fees are charged at an identical flat rate, that is if the same conditions apply for any customer, or if fees are not risk dependant, credit risk would be mispriced at the individual borrower level. A deeper investigation requires the use of individual borrower data to assess default risk, lending conditions and the price set for services (commission and fees) for each individual customer or for different categories of clientele.

\section{Data and results}

\subsection{Data set}

Our sample consists of an unbalanced panel of annual report data from 1996 to 2002 for a set of European commercial and cooperative banks established in 12 European countries: Austria, Belgium, Denmark, France, Italy, Netherlands, Norway, Portugal, Spain, Sweden, Switzerland, United Kingdom (see Appendix, Table A.1). The bank data used for the estimates come from Bankscope ${ }^{3}$. Apart from small German local cooperative banks (more than 1600 banks) that we deliberately ignore, Bankscope reported at the end of 2002 balance

\footnotetext{
${ }^{3}$ Some countries such as Greece and Germany are omitted in our sample because banks do not report information on the interest they receive from loans which we need to compute the implicit lending rates. For most countries we consider in our study, Bankscope provides information on the interest received from customer loans specifically. In the case of Belgium, Switzerland and the United Kingdom we are able to consider the following items respectively: interest receivable and similar income (which excludes income from variable-yield securities), interest and discount income (which excludes interest and dividend income on trading portfolios and financial investment) and interest received (which excludes interest received arising from debt securities and dividend income).
} 
sheets and income statements for 2129 banks for the countries we consider. Out of these 2129 banks we retain 602 banks in our sample. First, we delete 1333 banks with less than three years of time series observations ${ }^{4}$. Second, in order to minimize the effects of measurement errors we have excluded all the outliers (194 banks) by eliminating the extreme bank/year observations (2.5\% lowest values and $2.5 \%$ highest values) for each considered variable. We further check that the statistical properties of our clean sample of 602 banks and the initial sample of 2129 banks are similar by comparing the mean values of all our variables and by performing distribution tests. Data on market interest rates (3 months interbank rate and 10 year government bond rate) come from Datastream International.

Descriptive statistics of our sample (table 2) show sufficient heterogeneity in different types of banking activities, enabling us to analyse the behaviour of banks depending on their degree of product diversification.

\subsection{Results}

Tables 3 and 4 show the results which are obtained with two-way fixed effect panel data estimations (individual and time fixed effects). Fisher tests are used to determine if our data require the utilization of panel estimation or pooled estimation techniques. Heterogeneity across units leads us to use panel data estimations. Most panel data models are estimated under either fixed-effects or random-effects assumptions. We perform a Hausman test (see Hausman, 1978) to choose between these two basic models which leads us to use a fixed effect model (within estimator). We deal for possible heteroscedasticity by using the White methodology when estimating the equations.

On the whole, the coefficients of the standard variables considered in the literature on bank interest margin are significant and have the expected sign. The credit risk proxy (LLP) is significant and positive in each regression. This result is consistent with the hypothesis that banks charge higher lending rates for riskier loans.

The net non-interest income variable (NNII) introduced in equations [2] and [6] has a significant negative coefficient in all our panel data estimations suggesting possible crossselling of traditional lending activities and non interest generating activities.

To investigate this hypothesis, we consider as a first step non traditional income activities at a disaggregated level. More precisely, we split these activities into fee-based income and trading income. Equations [4] and [8] in tables 3 and 4 show that the coefficient

\footnotetext{
${ }^{4}$ All the banks in our sample publish their annual financial statements at the end of the calendar year.
} 
of COM (the income share of commission and fee income) is negative and significant. Thus, up to this stage our results are consistent with the hypothesis that banks decrease their lending rate when they are more reliant on fee generating products. Conversely the coefficient of the variable indicating the extent to which bank revenue is trading based (TRAD) is not significantly different from 0 except when the dependant variable is the margin from all interest generating activities (W_MARGIN) comprising loans but also other market assets such as securities. Therefore, our findings do not support evidence of any correlation between loan prices and the relative importance of income generated by trading activities.

As a second step, because our results suggest that banks might be cross-selling their products using loans as a loss leader and possibly underpricing credit risk, we further explore this issue by estimating the augmented models in which interacting variables are introduced to capture the presence of such a behaviour via a negative impact on the dependant variable (equations 9 to 14 in tables 5 and 6). Hence, the interacting variables stand for the mixed effect on risk pricing via the interest rate spread (risk premium) banks require on their loans. In this sense, banks may decrease their lending rate to attract or to retain borrowers which are potential customers for fee generating products. But their exposure to default risk may consequently become higher. In our study this effect is captured by a fall in the spread (risk premium) that is not consistent with the level of credit risk. The interacting variables are defined as the credit risk variable (LLP) multiplied by each of the non interest income variables (NNII, COMSHA, COM and TRAD). Whereas almost all the interacting variables are significant and negative in the margin equations (when the dependant variable is W_MARGIN or N_MARGIN, table 5) only the variables involving commission and fee income are significant in the spread equations (W_SPREAD or N_SPREAD, table 6). This means that for higher levels of commission and fee shares (COM), which are always positive by construction, a higher exposure to credit risk (LLP) has a lower effect on the interest rate spread (measured by the sum of the coefficients of LLP (positive) and LLP*COM (negative) which are highly significant in table 6$)^{5}$. Hence, according to our results the non interest income subsidy effect distorts credit risk pricing for banks expanding commission and fee activities but the development of trading activities does not significantly affect the link

\footnotetext{
${ }^{5}$ To assess the overall effect of credit risk on the dependent variable, one needs to consider not only the coefficient of LLP but also the coefficients of the interacting variables (LLP*NNII, LLP*COMSHA, LLP*COM or LLP*TRAD). More precisely, if we consider equation 12' in Table 6, the impact of credit risk on the dependent variable for a given bank which exhibits, for a given year, a value of NNII equal to $40 \%$, is equal to the coefficient of LLP + (the coefficient of LLP*NNII * the value of NNII taken by the bank): $0.664+(-1.097$ * 0.4 ) that is a value equal to 0.225 . In this case credit risk is not fully taken into account in the loan rate setting process (a coefficient of 0.225 instead of a coefficient of 0.664 without the cross-selling effect).
} 
between credit risk and the pricing of loans. As discussed above (section 2.2.), our results are based on the assumption that banks do not charge higher fees to borrowers with higher default risk. A deeper insight on this issue requires detailed data on individual borrower's default risk, lending conditions and fees paid for banking services.

\subsection{Robustness checks and further issues ${ }^{6}$}

Several robustness checks are performed. First, we deal with possible trend issues (decrease in interest margins due to higher competition and higher proportion of non interest generating activities at the end of the sample period) by running cross-section estimations for each year instead of introducing time fixed effects. OLS cross section results for 1996 and 2002 are presented in Tables A2, A3, A4 and A5 in the Appendix. We also run our estimations by introducing a time trend in our panel data models and for further checks by first differencing the variables. Overall, the main conclusions remain valid.

Our sample comprises large and small banks with different types of operations and clienteles and therefore our results need to be further checked by considering size effects. Because they might be serving larger borrowers with lower default risk large banks exhibit, in our sample, a lower lending rate on average. Again, in our sample, large banks are also slightly more diversified (higher share of non interest income) than small banks (see table A6 in the Appendix). Moreover, non interest income stems from various activities which are more innovation driven for large banking corporations but to a large extent linked to traditional activities for small local banks. We therefore conduct the estimations separately for large banks (total assets $>1$ billion Euros) and small banks (total assets $<1$ billion Euros). Our results show that small and large banks do not behave differently and that our findings are not biased by the fact that larger banks which exhibit lower lending rates are on average more diversified than small banks.

We also checked whether the level of diversification might possibly influence bank's strategies and therefore our results. At this end, we differentiate banks with relatively high and relatively low shares of commission and fee income (ratio of net commission income to net operating income, COM, higher than the third quartile $\mathrm{Q}_{75}$ and COM lower than the first quartile $\mathrm{Q}_{25}$ ). We then run the estimations separately for the two sub-samples of banks based on this criterion. Results are mainly the same for the two types of banks.

\footnotetext{
${ }^{6}$ The results from the estimations conducted in this section are available from the authors on request.
} 
We also consider as a sub-sample banks for which loan activities represent a significant share of their balance sheet (i.e. at least twenty percent of banks' total assets). Under this restriction it is assumed that to engage in cross-selling banks must have first developed loan activities to a certain extent. All conclusions concerning the variables of interest remain unchanged.

In addition we also perform a number of robustness checks that are more specification related. First, we include country dummies to capture the presence of country specific effects. Second, when calculating the spread, we use the three month interbank rate (instead of the ten year government bond rate). Our conclusions, regarding the inclusion of product diversification variables, are unaltered.

\section{Conclusion}

The objective of this study was to analyze the implications of the trend towards stronger product diversification in the European banking industry. In addition to risk related issues addressed in previous papers we test for a possible cross-selling behaviour of interest and non-interest products by analysing the determinants of the risk premium charged by banks on their loans. Specifically, we find that borrower default risk is underpriced in lending rates and on the whole our results show that higher reliance on fee-based activities is associated with lower lending rates. Therefore, our findings suggest that banks may use loans as a loss leader raising the issue of how cross-selling strategies should be addressed by regulators to control for bank risk. In this sense our results may explain the positive relationship between risk and bank product diversification found in some studies (De Young and Roland, 2001; Stiroh, 2004; Stiroh and Rumble, 2006; Baele et al. 2006; Lepetit et al. 2006). Conversely, we do not find evidence of any link with the growing share of trading activities in bank income statements.

Our conclusions are based on the assumption that banks do not charge higher fees when lending to more risky borrowers and that on average higher income from commission and fee activities does not serve as a buffer against default risk along with traditional instruments such as loan loss provisions. A deeper investigation on this issue requires access to more detailed data on individual borrower default risk and lending conditions but also on individual prices for banking services. Nevertheless, our findings suggest that there is a weaker link between provisions for expected loan losses (as measured by loan loss provisions) and expected loan losses for more diversified banks. 


\section{Table 1. Specification of spread and margin equations}

\begin{tabular}{|c|c|}
\hline MARGIN $_{\mathrm{it}}=\alpha_{\mathrm{it}}+\alpha_{2}$ R3M $_{\mathrm{j}(\mathrm{it} \mathrm{t}}+\alpha_{3}$ LLP $_{\mathrm{it}}+\alpha_{4}$ LIQUIDITY $_{\mathrm{it}}+\alpha_{5}$ EQUITY $_{\mathrm{it}}+\alpha_{6} \mathrm{TA}_{-} \mathrm{R}_{\mathrm{it}}+\alpha_{7}$ EXPENSES $_{\mathrm{it}}+\varepsilon_{\mathrm{it}}$ & [1] or [1'] \\
\hline MARGIN $_{\mathrm{it}}=\alpha_{\mathrm{it}}+\alpha_{2} \mathrm{R} \mathrm{M}_{\mathrm{j}(\mathrm{itt}}+\alpha_{3} \operatorname{LLP}_{\mathrm{it}}+\alpha_{4}$ LIQUIDITY $_{\mathrm{it}}+\alpha_{5}$ EQUITY $_{\mathrm{it}}+\alpha_{6} \mathrm{TA}_{-} \mathrm{R}_{\mathrm{it}}+\alpha_{7}$ EXPENSES $_{\mathrm{it}}+\alpha_{8} \mathrm{NNII}_{\mathrm{it}}+\varepsilon_{\mathrm{it}}$ & [2] or [2’] \\
\hline MARGIN $_{\mathrm{it}}=\alpha_{1 \mathrm{i}}+\alpha_{2}$ R3M $_{\mathrm{j}(\mathrm{i}) \mathrm{t}}+\alpha_{3}$ LLP $_{\mathrm{it}}+\alpha_{4}$ LIQUIDITY $_{\mathrm{it}}+\alpha_{5}$ EQUITY $_{\mathrm{it}}+\alpha_{6} \mathrm{TA}_{-} \mathrm{R}_{\mathrm{it}}+\alpha_{7}$ EXPENSES $_{\mathrm{it}}+\alpha_{8}$ NNII $_{\mathrm{it}}+\alpha_{9}$ COMSHA $_{\mathrm{it}}+\varepsilon_{\mathrm{it}}$ & [3] or [3'] \\
\hline MARGIN $_{\mathrm{it}}=\alpha_{1 \mathrm{i}}+\alpha_{2} \mathrm{R}_{3} \mathrm{M}_{\mathrm{j}(\mathrm{it})}+\alpha_{3}$ LLP $_{\mathrm{it}}+\alpha_{4}$ LIQUIDITY $_{\mathrm{it}}+\alpha_{5}$ EQUITY $_{\mathrm{it}}+\alpha_{6} \mathrm{TA}_{-} \mathrm{R}_{\mathrm{it}}+\alpha_{7}$ EXPENSES $_{\mathrm{it}}+\alpha_{10} \mathrm{COM}_{\mathrm{it}}+\alpha_{11} \operatorname{TRAD}_{\mathrm{it}}+\varepsilon_{\mathrm{it}}$ & [4] or [4'] \\
\hline MARGIN $_{\mathrm{it}}=\alpha_{1 \mathrm{i}}+\alpha_{2}$ R3M $_{\mathrm{j}(\mathrm{i}) \mathrm{t}}+\alpha_{3} \operatorname{LLP}_{\mathrm{it}}+\alpha_{4}$ LIQUIDITY $_{\mathrm{it}}+\alpha_{5}$ EQUITY $_{\mathrm{it}}+\alpha_{6} \mathrm{TA}_{-} \mathrm{R}_{\mathrm{it}}+\alpha_{7}$ EXPENSES $_{\mathrm{it}}+\alpha_{12}\left(\operatorname{LLP}_{\mathrm{it}} \times \mathrm{NNII}_{\mathrm{it}}\right) / 100+\varepsilon_{\mathrm{it}}$ & [9] or [9’] \\
\hline \multicolumn{2}{|c|}{ 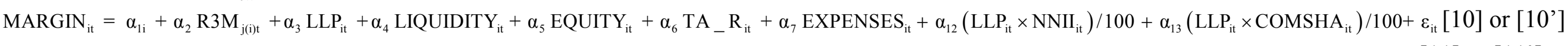 } \\
\hline 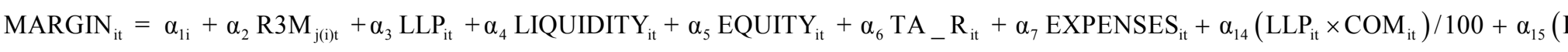 & $-\varepsilon_{\mathrm{it}}[11]$ or $\left[11^{\prime}\right]$ \\
\hline
\end{tabular}

\begin{tabular}{|c|c|}
\hline SPREAD $_{\mathrm{it}}=\beta_{1 \mathrm{i}}+\beta_{2}$ VR3M $_{\mathrm{jt}}+\beta_{3}$ LLP $_{\mathrm{it}}+\beta_{4}$ EQUITY $_{\mathrm{it}}+\beta_{5} \mathrm{TA}_{-} \mathrm{R}_{\mathrm{it}}+\beta_{6}$ EXPENSES $_{\mathrm{it}}+\varepsilon_{\mathrm{it}}$ & [5] or [5'] \\
\hline $\operatorname{SPREAD}_{\mathrm{it}}=\beta_{1 \mathrm{it}}+\beta_{2} \mathrm{VR}_{3} \mathrm{M}_{\mathrm{jt}}+\beta_{3} \mathrm{LLP}_{\mathrm{it}}+\beta_{4}$ EQUITY $_{\mathrm{it}}+\beta_{5} \mathrm{TA}_{-} \mathrm{R}_{\mathrm{it}}+\beta_{6}$ EXPENSES $_{\mathrm{it}}+\beta_{7} \mathrm{NNII}_{\mathrm{it}}+\varepsilon_{\mathrm{it}}$ & [6] or [6’] \\
\hline $\operatorname{SPREAD}_{\mathrm{it}}=\beta_{1 \mathrm{i}}+\beta_{2} \mathrm{VR}_{\mathrm{jt}}+\beta_{3} \mathrm{LLP}_{\mathrm{it}}+\beta_{4}$ EQUITY $_{\mathrm{it}}+\beta_{5} \mathrm{TA}_{-} \mathrm{R}_{\mathrm{it}}+\beta_{6}$ EXPENSES $_{\mathrm{it}}+\beta_{7} \mathrm{NNII}_{\mathrm{it}}+\beta_{8} \mathrm{COMSHA}_{\mathrm{it}}+\varepsilon_{\mathrm{it}}$ & [7] or [7’] \\
\hline $\operatorname{SPREAD}_{\mathrm{it}}=\beta_{1 \mathrm{it}}+\beta_{2} \mathrm{VR} \mathrm{M}_{\mathrm{jt}}+\beta_{3} \mathrm{LLP}_{\mathrm{it}}+\beta_{4}$ EQUITY $_{\mathrm{it}}+\beta_{5} \mathrm{TA}_{-} \mathrm{R}_{\mathrm{it}}+\beta_{6}$ EXPENSES $_{\mathrm{it}}+\beta_{9} \mathrm{COM}_{\mathrm{it}}+\beta_{10} \mathrm{TRAD}_{\mathrm{it}}+\varepsilon_{\mathrm{it}}$ & [8] or [8'] \\
\hline SPREAD $_{\mathrm{it}}=\beta_{1 \mathrm{i}}+\beta_{2}{\mathrm{VR} 3 \mathrm{M}_{\mathrm{jt}}}+\beta_{3} \operatorname{LLP}_{\mathrm{it}}+\beta_{4}$ EQUITY $_{\mathrm{it}}+\beta_{5} \mathrm{TA}_{-} \mathrm{R}_{\mathrm{it}}+\beta_{6}$ EXPENSES $_{\mathrm{it}}+\beta_{11}\left(\mathrm{LLP}_{\mathrm{it}} \times \mathrm{NNII}_{\mathrm{it}}\right) / 100+\varepsilon_{\mathrm{it}}$ & [12] or [12'] \\
\hline $\operatorname{SPREAD}_{\mathrm{it}}=\beta_{1 \mathrm{i}}+\beta_{2} \mathrm{VR} \mathrm{M}_{\mathrm{jt}}+\beta_{3} \operatorname{LLP}_{\mathrm{it}}+\beta_{4}$ EQUITY $_{\mathrm{it}}+\beta_{5} \mathrm{TA}_{-} \mathrm{R}_{\mathrm{it}}+\beta_{6}$ EXPENSES $_{\mathrm{it}}+\beta_{11}\left(\operatorname{LLP}_{\mathrm{it}} \times \mathrm{NNII}_{\mathrm{it}}\right) / 100+\beta_{12}\left(\operatorname{LLP}_{\mathrm{it}} \times \operatorname{COMSHA}_{\mathrm{it}}\right) / 100+\varepsilon_{\mathrm{it}}$ & [13] or [13'] \\
\hline $\operatorname{SPREAD}_{\mathrm{it}}=\beta_{1 \mathrm{i}}+\beta_{2} \mathrm{VR}_{3 M_{\mathrm{jt}}}+\beta_{3} \operatorname{LLP}_{\mathrm{it}}+\beta_{4}$ EQUITY $_{\mathrm{it}}+\beta_{5} \mathrm{TA}_{-} \mathrm{R}_{\mathrm{it}}+\beta_{6}$ EXPENSES $_{\mathrm{it}}+\beta_{13}\left(\operatorname{LLP}_{\mathrm{it}} \times \operatorname{COM}_{\mathrm{it}}\right) / 100+\beta_{14}\left(\operatorname{LLP}_{\mathrm{it}} \times \mathrm{TRAD}_{\mathrm{it}}\right) / 100+\varepsilon_{\mathrm{it}}$ & [14] or [14'] \\
\hline
\end{tabular}

$i$ and $t$ are respectively indices for banks $i$ and time

MARGIN $_{\text {it }}$ is defined either as:

W_MARGIN = net interest income/total earning assets (equations 1 to 4 and equations 9 to 11 );

or N_MARGIN = interest from loans/net loans - interest expenses/total liabilities (equations 1' to 4' and equations 9' to 11 ');

SPREAD ${ }_{\text {it }}$ is defined either as:

W_SPREAD $=$ net interest income/total earning assets - the ten year government bond rate (equations 5 to 8 and equations 12 to 14 );

or N SPREAD = interest from loans/net loans - the ten year government bond rate (equations 5' to 8' and equations 12 ' to 14 ');

$R 3 \mathrm{M}_{\mathrm{jt}}$ : the three months interbank rate for country $\mathrm{j}$ of bank $\mathrm{i}$ at time $\mathrm{t}$;
VR3 $\mathrm{M}_{\mathrm{j} t}$ : Volatility of the three months interbank rate (standard deviation computed with daily data) for country $j$;

$\mathrm{LLP}_{\mathrm{it}}=$ loan loss provisions/net loans;

LIQUIDITY $_{\text {it }}=$ net loans/deposits;

EQUITY $\mathrm{it}_{\text {it }}=$ equity/total assets;

$\mathrm{TA} \mathrm{R}_{\mathrm{it}}=$ total assets for bank $\mathrm{i}$ divided by the sum of the total assets of the banking system

EXPENSES $_{\text {it }}=$ personnel expenses/total assets;

$\mathrm{NNII}_{\text {it }}=$ net non-interest income/total net operating income;

$\mathrm{COM}_{\mathrm{it}}=$ net commission and fee income/ total net operating income;

$\mathrm{TRAD}_{\text {it }}=$ net trading income/ total net operating income;

$\mathrm{COMSHA}_{\mathrm{it}}=$ net commission and fee income/ net non-interest income. 
Table 2. Descriptive statistics for European commercial and cooperative banks, on average over the period 1996-2002

\begin{tabular}{|c|c|c|c|c|c|c|c|c|c|c|c|c|c|c|c|c|}
\hline & LOANS & DEP & EQUITY & LLP & EXPENSES & ROA & $\mathrm{ROE}$ & W_MARGIN & N_MARGIN & W SPREAD & N SPREAD & NII & NNII & $\mathrm{COM}$ & TRAD & TA \\
\hline Mean & 60.64 & 52.18 & 8.77 & 0.67 & 1.62 & 0.79 & 9.30 & 2.79 & 0.93 & 1.40 & 1.40 & 65.51 & 34.48 & 27.00 & 6.03 & 18546 \\
\hline Max & 95.93 & 91.89 & 53.42 & 9.28 & 21.48 & 16.08 & 68.99 & 10.42 & 18.18 & 16.16 & 25.83 & 100 & 99.96 & 96.77 & 78.35 & 745000 \\
\hline Min & 5.69 & 0.75 & 0.42 & -2.02 & 0.07 & -14.87 & -175.77 & 0 & -23.42 & -4.15 & -5.35 & 0.03 & 0 & -18.31 & -70.80 & 17 \\
\hline Std & 17.45 & 16.06 & 5.82 & 0.72 & 1.11 & 1.00 & 10.13 & 1.20 & 4.58 & 1.72 & 3.06 & 18.94 & 18.94 & 15.77 & 8.69 & 69238 \\
\hline
\end{tabular}

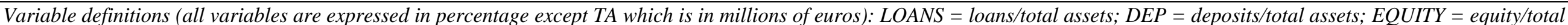

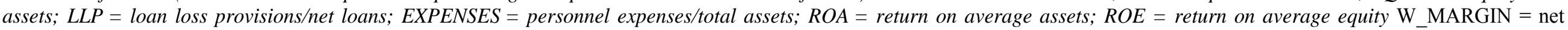

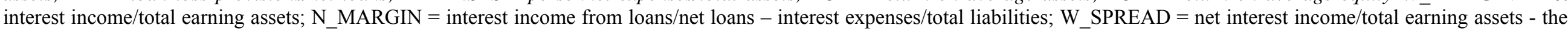

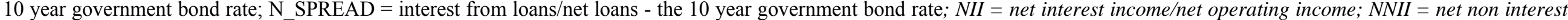
income/ net operating income; $C \bar{O} M=$ net commission income/net operating income; TRAD = net trading income/net operating income; TA : total assets in millions of euros. 
Table 3. Two way fixed effect regression (LSDV): impact of product diversification on net interest margin for European banks (1996-2002)

\begin{tabular}{|c|c|c|c|c|c|c|c|c|c|c|c|}
\hline Equation & $\begin{array}{c}\mathrm{R} 3 \mathrm{M} \\
(+)\end{array}$ & $\begin{array}{l}\text { LLP } \\
(+)\end{array}$ & $\begin{array}{c}\text { LIQUIDITY } \\
(+)\end{array}$ & $\begin{array}{c}\text { EQUITY } \\
(+)\end{array}$ & $\begin{array}{c}\text { EXPENSES } \\
(+/-)\end{array}$ & $\begin{array}{c}\text { TA_R } \\
(+/-)\end{array}$ & $\begin{array}{c}\text { NNII } \\
(-)\end{array}$ & $\begin{array}{c}\text { COMSHA } \\
(-)\end{array}$ & $\begin{array}{c}\mathrm{COM} \\
(-)\end{array}$ & $\begin{array}{c}\text { TRAD } \\
(-)\end{array}$ & $\mathrm{R}^{2}$ \\
\hline \multicolumn{12}{|c|}{ Dependant variable: W_MARGIN (2342 obs.) } \\
\hline$[1]$ & $\begin{array}{c}0.115^{* * *} \\
(5.622)\end{array}$ & $\begin{array}{c}0.071 * * * \\
(3.850)\end{array}$ & $\begin{array}{l}0.000^{*} \\
(1.760)\end{array}$ & $\begin{array}{c}0.035 * * * \\
(4.715)\end{array}$ & $\begin{array}{c}0.404 * * * \\
(6.433)\end{array}$ & $\begin{array}{c}0.137 \\
(0.094)\end{array}$ & - & - & - & - & 0.920 \\
\hline$[2]$ & $\begin{array}{c}0.100 * * * \\
(3.955)\end{array}$ & $\begin{array}{c}0.047 * * \\
(2.443)\end{array}$ & $\begin{array}{c}-0.000 \\
(-0.076)\end{array}$ & $\begin{array}{c}0.032 * * * \\
(4.449)\end{array}$ & $\begin{array}{c}0.415 * * * \\
(6.653)\end{array}$ & $\begin{array}{c}0.304 \\
(0.275)\end{array}$ & $\begin{array}{c}-0.019 * * * \\
(-5.308)\end{array}$ & - & - & - & 0.929 \\
\hline$[3]$ & $\begin{array}{c}0.098 * * * \\
(3.921)\end{array}$ & $\begin{array}{c}0.047 * * \\
(2.409)\end{array}$ & $\begin{array}{c}-0.000 \\
(-0.062)\end{array}$ & $\begin{array}{c}0.032 * * * \\
(4.406)\end{array}$ & $\begin{array}{c}0.413 * * * \\
(6.558)\end{array}$ & $\begin{array}{c}0.344 \\
(0.316)\end{array}$ & $\begin{array}{c}-0.020 * * * \\
(-5.243)\end{array}$ & $\begin{array}{c}-0.019 \\
(-1.455)\end{array}$ & - & - & 0.929 \\
\hline$[4]$ & $\begin{array}{c}0.067 * * * \\
(3.890)\end{array}$ & $\begin{array}{c}0.048 * * \\
(2.608)\end{array}$ & $\begin{array}{c}0.000 \\
(0.216) \\
\end{array}$ & $\begin{array}{c}0.028 * * * \\
(3.993)\end{array}$ & $\begin{array}{c}0.420 * * * \\
(6.415)\end{array}$ & $\begin{array}{c}-0.665 \\
(-0.582)\end{array}$ & - & - & $\begin{array}{c}-0.037 * * * \\
(-8.911)\end{array}$ & $\begin{array}{c}-0.016 * * * \\
(-8.026)\end{array}$ & 0.934 \\
\hline \multicolumn{12}{|c|}{ Dependant variable: $N \_$MARGIN (2342 obs.) } \\
\hline$\left[1^{\prime}\right]$ & $\begin{array}{c}0.140 * * * \\
(3.923)\end{array}$ & $\begin{array}{c}0.149^{* * *} \\
(5.067)\end{array}$ & $\begin{array}{l}-0.001^{*} \\
(-1.680)\end{array}$ & $\begin{array}{l}-0.070^{*} \\
(-1.769)\end{array}$ & $\begin{array}{c}0.204 \\
(1.635)\end{array}$ & $\begin{array}{c}1.672 \\
(0.691)\end{array}$ & - & - & - & - & 0.799 \\
\hline$\left[2^{\prime}\right]$ & $\begin{array}{c}0.159 * * * \\
(5.349)\end{array}$ & $\begin{array}{c}0.114 * * * \\
(3.390)\end{array}$ & $\begin{array}{c}-0.000 * * * \\
(-4.861)\end{array}$ & $\begin{array}{c}-0.022 \\
(-0.819)\end{array}$ & $\begin{array}{c}0.135 \\
(1.045)\end{array}$ & $\begin{array}{l}1.707 \\
(0.748)\end{array}$ & $\begin{array}{c}-0.010^{* *} \\
(-1.967)\end{array}$ & - & - & - & 0.843 \\
\hline$\left[3^{\prime}\right]$ & $\begin{array}{c}0.158 * * * \\
(5.232)\end{array}$ & $\begin{array}{c}0.110 * * * \\
(3.190)\end{array}$ & $\begin{array}{c}-0.000 * * * \\
(-4.834)\end{array}$ & $\begin{array}{c}-0.023 \\
(-0.837)\end{array}$ & $\begin{array}{c}0.132 \\
(1.015)\end{array}$ & $\begin{array}{l}1.641 \\
(0.727)\end{array}$ & $\begin{array}{l}-0.010 * \\
(-1.800)\end{array}$ & $\begin{array}{c}-0.009 \\
(-0.576)\end{array}$ & - & - & 0.843 \\
\hline$\left[4^{\prime}\right]$ & $\begin{array}{c}0.200 * * * \\
(5.072)\end{array}$ & $\begin{array}{c}0.033 \\
(1.307)\end{array}$ & $\begin{array}{c}-0.000 * * * \\
(-4.342)\end{array}$ & $\begin{array}{c}-0.010 \\
(-0.310)\end{array}$ & $\begin{array}{c}0.082 \\
(0.461)\end{array}$ & $\begin{array}{c}4.262 \\
(1.089)\end{array}$ & - & - & $\begin{array}{c}-0.017 * * \\
(-1.986)\end{array}$ & $\begin{array}{c}-0.006 \\
(-1.357)\end{array}$ & 0.839 \\
\hline
\end{tabular}

Variable definitions: $W \_M A R G I N=$ net interest income/total earning assets; $N$ MARGIN = (interest from loans/net loans) - interest expenses/total liabiities; LIQUIDITY ${ }_{\text {it }}=$ net loans/deposits; TA $R_{i t}=$ total assets for bank $i$ divided by the sum of the total asset of the banking system; $R 3 M_{j t}=$ the three months interbank rate; LLP $P_{i t}=$ loan loss

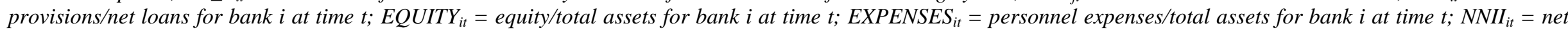
non-interest income/ total net operating income for bank i at time $t ; C_{i t}=$ net commission and fee income/ total net operating income for bank i at time $t ;$ TRAD $_{i t}=$ net trading income/ total net operating income for bank i at time $t ;$ COMSHA $_{i t}=$ net commission and fee income/ net non-interest income. 
Table 4. Two way fixed effect regression (LSDV): impact of product diversification on risk premium for European banks (1996-2002)

\begin{tabular}{|c|c|c|c|c|c|c|c|c|c|c|}
\hline Equation & $\begin{array}{c}\text { VR3M } \\
(+)\end{array}$ & $\begin{array}{l}\text { LLP } \\
(+)\end{array}$ & $\begin{array}{c}\text { EQUITY } \\
(+)\end{array}$ & $\begin{array}{c}\text { EXPENSES } \\
(+/-)\end{array}$ & $\begin{array}{c}\text { TA_R } \\
(+/-)\end{array}$ & $\begin{array}{l}\text { NNII } \\
(-)\end{array}$ & $\begin{array}{c}\text { COMSHA } \\
(-)\end{array}$ & $\begin{array}{c}\mathrm{COM} \\
(-)\end{array}$ & $\begin{array}{c}\text { TRAD } \\
(-)\end{array}$ & $\mathrm{R} 2$ \\
\hline \multicolumn{11}{|c|}{ Dependant variable: W_SPREAD (2342 obs.) } \\
\hline [5] & $\begin{array}{c}0.942 \\
(1.527)\end{array}$ & $\begin{array}{c}0.145^{* * *} \\
(3.065)\end{array}$ & $\begin{array}{c}0.007 \\
(0.517)\end{array}$ & $\begin{array}{c}0.335^{*} \\
(1.740)\end{array}$ & $\begin{array}{c}9.924 \\
(1.537)\end{array}$ & - & - & - & - & 0.776 \\
\hline$[6]$ & $\begin{array}{c}0.899 \\
(1.516)\end{array}$ & $\begin{array}{c}0.136 * * * \\
(2.817)\end{array}$ & $\begin{array}{l}-0.014 * * \\
(-2.097)\end{array}$ & $\begin{array}{c}0.629 * * * \\
(4.698)\end{array}$ & $\begin{array}{c}9.608 \\
(1.414)\end{array}$ & $\begin{array}{c}-0.015 * * * \\
(-2.642)\end{array}$ & - & - & - & 0.790 \\
\hline$[7]$ & $\begin{array}{c}0.891 \\
(1.526)\end{array}$ & $\begin{array}{c}0.138 * * * \\
(2.852)\end{array}$ & $\begin{array}{l}-0.015 * * \\
(-2.068)\end{array}$ & $\begin{array}{c}0.627 * * * \\
(4.699)\end{array}$ & $\begin{array}{c}9.550 \\
(1.424)\end{array}$ & $\begin{array}{c}-0.016 * * * \\
(-2.659)\end{array}$ & $\begin{array}{l}-0.065^{*} \\
(-1.853)\end{array}$ & - & - & 0.791 \\
\hline$[8]$ & $\begin{array}{c}0.733 \\
(1.528) \\
\end{array}$ & $\begin{array}{c}0.124 * * \\
(2.430)\end{array}$ & $\begin{array}{c}0.002 \\
(0.116)\end{array}$ & $\begin{array}{c}0.251 \\
(1.343)\end{array}$ & $\begin{array}{c}6.978 \\
(1.322)\end{array}$ & & - & $\begin{array}{c}-0.053 * * * \\
(-2.838)\end{array}$ & $\begin{array}{c}-0.001 \\
(-0.262)\end{array}$ & 0.791 \\
\hline \multicolumn{11}{|c|}{ Dependant variable: N_SPREAD (2342 obs.) } \\
\hline [5’] & $\begin{array}{l}0.973^{*} \\
(1.669)\end{array}$ & $\begin{array}{c}0.231 * * * \\
(4.697)\end{array}$ & $\begin{array}{c}-0.006 \\
(-0.296)\end{array}$ & $\begin{array}{c}0.224 * * * \\
(2.914)\end{array}$ & $\begin{array}{c}4.417 \\
(1.429)\end{array}$ & - & - & - & - & 0.815 \\
\hline [6’] & $\begin{array}{l}0.954^{*} \\
(1.676)\end{array}$ & $\begin{array}{c}0.240 * * * \\
(5.201)\end{array}$ & $\begin{array}{c}-0.013 \\
(-0.589)\end{array}$ & $\begin{array}{c}0.324 * * * \\
(5.205)\end{array}$ & $\begin{array}{c}4.180 \\
(1.351)\end{array}$ & $\begin{array}{c}-0.014 * * * \\
(-3.012)\end{array}$ & - & - & - & 0.818 \\
\hline$\left[7^{\prime}\right]$ & $\begin{array}{l}0.949^{*} \\
(1.685)\end{array}$ & $\begin{array}{c}0.234 * * * \\
(5.093)\end{array}$ & $\begin{array}{c}-0.014 \\
(-0.620)\end{array}$ & $\begin{array}{c}0.316 * * * \\
(5.077)\end{array}$ & $\begin{array}{c}4.091 \\
(1.318)\end{array}$ & $\begin{array}{c}-0.014 * * * \\
(-2.784)\end{array}$ & $\begin{array}{c}-0.053 * * \\
(-2.257)\end{array}$ & - & - & 0.818 \\
\hline$\left[8^{\prime}\right]$ & $\begin{array}{c}0.717 \\
(1.177)\end{array}$ & $\begin{array}{c}0.141 * * * \\
(3.195)\end{array}$ & $\begin{array}{c}-0.006 \\
(-0.293)\end{array}$ & $\begin{array}{c}0.197 * * \\
(2.165)\end{array}$ & $\begin{array}{c}7.523 * * * \\
(3.558)\end{array}$ & - & - & $\begin{array}{c}-0.046^{* *} \\
(-2.619)\end{array}$ & $\begin{array}{l}-0.006^{*} \\
(-1.943)\end{array}$ & 0.807 \\
\hline
\end{tabular}

Variable definitions: W SPREAD = the ratio of net interest income to total earning assets - the 10 year government bond rate; $N$ SPREAD = lending rate determined as the ratio of interest from loans to net loans - the 10 year government bond rate; TA_ $R_{i t}=$ total assets for bank $i$ divided by the sum of the total asset of the banking system; $V R 3 M_{j t}=$ volatility of the three months interbank rate (standard deviation computed with daily data) for country $j ;$ LLP it $=$ loan loss provisions/net loans for bank $i$ at time $t ;$ EQUITY $_{\text {it }}=$ equity/total assets for bank $i$ at time $t$; EXPENSES $S_{i t}=$ personnel expenses/total assets for bank $i$ at time $t ;$ NNII $_{i t}=$ net non-interest income/ total net operating income for bank $i$ at time $t$; $C O M_{i t}=$ net commission and fee income/ total net operating income for bank i at time $t$; TRAD $D_{i t}=$ net trading income/ total net operating income for bank $i$ at time $t$; COMSHA it $_{1}$ net commission and fee income/ net non-interest income. 
Table 5. Two way fixed effect regression (LSDV): impact of interacting variables (product diversification*credit risk) on net interest margin for European banks (1996-2002)

\begin{tabular}{|c|c|c|c|c|c|c|c|c|c|c|c|}
\hline & $\begin{array}{l}\text { R3M } \\
(+)\end{array}$ & $\begin{array}{c}\text { LLP } \\
(+)\end{array}$ & $\begin{array}{l}\text { LIQUIDITY } \\
(+)\end{array}$ & $\begin{array}{c}\text { EQUITY } \\
(+)\end{array}$ & $\begin{array}{c}\text { EXPENSES } \\
(+/-)\end{array}$ & $\begin{array}{c}\text { TA_R } \\
(+/-)\end{array}$ & $\begin{array}{c}\text { LLP* NNII }^{*} \\
\qquad 100 \\
(-)\end{array}$ & $\begin{array}{c}\text { LLP*COMSHA } \\
/ 100 \\
(-)\end{array}$ & $\begin{array}{c}\text { LLP*COM } \\
\qquad 100 \\
(-)\end{array}$ & $\begin{array}{c}\text { LLP*TRAD } \\
/ 100 \\
(-)\end{array}$ & $\mathrm{R}^{2}$ \\
\hline \multicolumn{12}{|c|}{ Dependant variable: W_MARGIN (2342 obs.) } \\
\hline [9] & $\begin{array}{c}0.108^{* * * *} \\
(5.590)\end{array}$ & $\begin{array}{c}0.234 * * * \\
(4.056)\end{array}$ & $\begin{array}{c}0.000 \\
(1.517)\end{array}$ & $\begin{array}{c}0.037 * * * \\
(5.987)\end{array}$ & $\begin{array}{c}0.390 * * * \\
(6.640)\end{array}$ & $\begin{array}{c}0.232 \\
(0.169)\end{array}$ & $\begin{array}{c}-0.452 * * * \\
(-3.343)\end{array}$ & - & - & - & 0.922 \\
\hline$[10]$ & $\begin{array}{c}0.106^{* * * *} \\
(5.641)\end{array}$ & $\begin{array}{c}0.245 * * * \\
(3.763)\end{array}$ & $\begin{array}{c}0.000 \\
(1.508)\end{array}$ & $\begin{array}{c}0.037 * * * \\
(5.941)\end{array}$ & $\begin{array}{c}0.388 * * * \\
(6.542)\end{array}$ & $\begin{array}{c}0.285 \\
(0.208)\end{array}$ & $\begin{array}{c}-0.461 * * * \\
(-3.233)\end{array}$ & $\begin{array}{c}-1.198 \\
(-0.886)\end{array}$ & - & - & 0.922 \\
\hline$[11]$ & $\begin{array}{c}0.102 * * * \\
(5.492)\end{array}$ & $\begin{array}{c}0.273 * * * \\
(5.453)\end{array}$ & $\begin{array}{c}0.000 \\
(1.621)\end{array}$ & $\begin{array}{c}0.036^{* * *} \\
(5.656)\end{array}$ & $\begin{array}{c}0.394 * * * \\
(6.493)\end{array}$ & $\begin{array}{c}0.237 \\
(0.173)\end{array}$ & - & - & $\begin{array}{c}-0.505 * * * \\
(-4.280)\end{array}$ & $\begin{array}{c}-0.215^{* *} \\
(-2.240)\end{array}$ & 0.923 \\
\hline \multicolumn{12}{|c|}{ Dependant variable: $N$ MARGIN (2342 obs.) } \\
\hline$\left[9^{\prime}\right]$ & $\begin{array}{c}0.156^{* * *} \\
(5.700)\end{array}$ & $\begin{array}{c}0.412 * * * \\
(8.794)\end{array}$ & $\begin{array}{c}-0.000 * * * \\
(-5.112)\end{array}$ & $\begin{array}{c}-0.018 \\
(-0.694)\end{array}$ & $\begin{array}{c}0.115 \\
(0.981)\end{array}$ & $\begin{array}{c}2.157 \\
(0.866)\end{array}$ & $\begin{array}{c}-0.624 * * * \\
(-4.669)\end{array}$ & - & - & - & 0.843 \\
\hline [10’] & $\begin{array}{c}0.156^{* * * *} \\
(5.509)\end{array}$ & $\begin{array}{c}0.392 * * * \\
(5.642)\end{array}$ & $\begin{array}{c}-0.000 * * * \\
(-5.079)\end{array}$ & $\begin{array}{l}-0.018 \\
(-0.689)\end{array}$ & $\begin{array}{c}0.111 \\
(0.949)\end{array}$ & $\begin{array}{c}2.134 \\
(0.869)\end{array}$ & $\begin{array}{c}-0.636 * * * \\
(-4.552)\end{array}$ & $\begin{array}{c}1.412 \\
(0.330)\end{array}$ & - & - & 0.844 \\
\hline [11'] & $\begin{array}{c}0.212 * * * \\
(6.361)\end{array}$ & $\begin{array}{c}0.332 * * * \\
(4.165)\end{array}$ & $\begin{array}{c}-0.000 * * * \\
(-4.465)\end{array}$ & $\begin{array}{l}-0.006 \\
(-0.179)\end{array}$ & $\begin{array}{c}0.074 \\
(0.426)\end{array}$ & $\begin{array}{c}4.717 \\
(1.226)\end{array}$ & - & - & $\begin{array}{c}-0.589 * * * \\
(-2.674)\end{array}$ & $\begin{array}{c}-0.752 * * * \\
(-2.298)\end{array}$ & 0.840 \\
\hline
\end{tabular}

***, ** and * indicate significance respectively at the 1\%, 5\% and 10\% levels. $t$-statistics are corrected for heteroskedasticity following White's methodology.

Variable definitions: $W \_M A R G I N=$ net interest income/total earning assets; $N \_M A R G I N=($ interest from loans/net loans) - interest expenses/total liabiities; LIQUIDITY net loans/deposits; TA_ $R_{i t}=$ total assets for bank $i$ divided by the sum of the total asset of the banking system; $R 3 M_{j t}=$ the three months interbank rate; LLP $P_{i t}=$ loan loss provisions/net loans for bank $i$ at time $t ; E_{\text {EUITY }}$ it $=$ equity/total assets for bank $i$ at time $t ;$ EXPENSES it $=$ personnel expenses/total assets for bank $i$ at time $t ; L_{L} P_{i t} * N N I I_{i t}=$ $L L P^{*}$ (net non-interest income/ total net operating income) for bank $i$ at time $t ; L L P_{i t}{ }^{*} C O M_{i t}=L L P *$ (net commission and fee income/ total net operating income) for bank $i$ at time $t ; L L P_{i t} * T R A D_{i t}=L L P *$ (net trading income/ total net operating income) for bank $i$ at time $t$; $L L P_{i t} * C O M S H A_{i t}=L L P *(n e t$ commission and fee income/ net noninterest income). All the variables are expressed in \%. Therefore, the interacting variables are divided by 100 to obtain coefficients that can be directly compared to the coefficient of LLP. 
Table 6. Two way fixed effect regression (LSDV): impact of interacting variables (product diversification*credit risk) on risk premium for European banks (1996-2002)

\begin{tabular}{|c|c|c|c|c|c|c|c|c|c|c|}
\hline & $\begin{array}{l}\text { VR3M } \\
(+)\end{array}$ & $\begin{array}{r}\text { LLP } \\
(+)\end{array}$ & $\begin{array}{l}\text { EQUITY } \\
(+)\end{array}$ & $\begin{array}{c}\text { EXPENSES } \\
(+/-)\end{array}$ & $\begin{array}{c}\text { TA_R } \\
(+/-)\end{array}$ & $\begin{array}{c}\text { NNII*LLP/100 } \\
(-)\end{array}$ & $\begin{array}{c}\mathrm{LLP}^{*} \mathrm{COMSHA} / 100 \\
(-)\end{array}$ & $\begin{array}{c}\mathrm{LLP}^{*} \mathrm{COM}^{*} / 100 \\
(-)\end{array}$ & $\begin{array}{c}\text { LLP*TRAD/100 } \\
(-)\end{array}$ & $\mathrm{R} 2$ \\
\hline \multicolumn{11}{|c|}{ Dependant variable: W_SPREAD (2342 obs.) } \\
\hline$[12]$ & $\begin{array}{c}0.840 \\
(1.420)\end{array}$ & $\begin{array}{c}0.437 * * * \\
(3.805)\end{array}$ & $\begin{array}{c}-0.025 * * * \\
(-3.158)\end{array}$ & $\begin{array}{c}0.831 * * * \\
(7.022)\end{array}$ & $\begin{array}{l}9.203 \\
(1.631)\end{array}$ & $\begin{array}{c}-0.615^{* * *} \\
(-3.408)\end{array}$ & - & - & - & 0.789 \\
\hline$[13]$ & $\begin{array}{c}0.833 \\
(1.416)\end{array}$ & $\begin{array}{c}0.479 * * * \\
(4.293)\end{array}$ & $\begin{array}{c}-0.025 * * * \\
(-3.227)\end{array}$ & $\begin{array}{c}0.829 * * * \\
(6.977)\end{array}$ & $\begin{array}{c}9.172 \\
(1.640)\end{array}$ & $\begin{array}{c}-0.628 * * * \\
(-3.493)\end{array}$ & $\begin{array}{l}-4.114^{*} \\
(-1.744)\end{array}$ & - & - & 0.789 \\
\hline$[14]$ & $\begin{array}{c}0.788 \\
(1.402)\end{array}$ & $\begin{array}{c}0.598 * * * \\
(6.628)\end{array}$ & $\begin{array}{c}-0.024 * * * \\
(-3.125)\end{array}$ & $\begin{array}{c}0.829 * * * \\
(7.536)\end{array}$ & $\begin{array}{c}8.656 \\
(1.592) \\
\end{array}$ & - & - & $\begin{array}{c}-1.218^{* * *} \\
(-8.289)\end{array}$ & $\begin{array}{c}-0.007 \\
(-0.149)\end{array}$ & 0.791 \\
\hline \multicolumn{11}{|c|}{ Dependant variable: N_SPREAD (2342 obs.) } \\
\hline$\left[12^{\prime}\right]$ & $\begin{array}{c}0.850 \\
(1.247)\end{array}$ & $\begin{array}{c}0.664 * * * \\
(5.311)\end{array}$ & $\begin{array}{c}-0.006 \\
(-0.224)\end{array}$ & $\begin{array}{c}0.333 * * * \\
(3.289)\end{array}$ & $\begin{array}{c}8.582 * * * \\
(4.325)\end{array}$ & $\begin{array}{c}-1.097 * * * \\
(-4.864)\end{array}$ & - & - & - & 0.807 \\
\hline [13'] & $\begin{array}{c}0.847 \\
(1.243)\end{array}$ & $\begin{array}{c}0.682 * * * \\
(5.279)\end{array}$ & $\begin{array}{c}-0.006 \\
(-0.252)\end{array}$ & $\begin{array}{c}0.331 * * * \\
(3.285)\end{array}$ & $\begin{array}{c}8.503 * * * \\
(4.261)\end{array}$ & $\begin{array}{c}-0.943 * * * \\
(-4.499)\end{array}$ & $\begin{array}{c}-5.407 \\
(-1.490)\end{array}$ & - & - & 0.808 \\
\hline [14'] & $\begin{array}{c}0.838 \\
(1.208) \\
\end{array}$ & $\begin{array}{c}0.659 * * * \\
(5.972)\end{array}$ & $\begin{array}{c}-0.005 \\
(-0.188) \\
\end{array}$ & $\begin{array}{c}0.327 * * * \\
(3.261) \\
\end{array}$ & $\begin{array}{c}8.600 * * * \\
(4.303)\end{array}$ & - & - & $\begin{array}{c}-1.047 * * * \\
(-4.120)\end{array}$ & $\begin{array}{c}-0.701 \\
(-0.075) \\
\end{array}$ & 0.807 \\
\hline
\end{tabular}

Variable definitions: W SPREAD = the ratio of net interest income to total earning assets - the 10 year government bond rate; $N$ SPREAD = lending rate determined as the ratio of interest from loans to net loans - the 10 year government bond rate; TA_ $R_{i t}=$ total assets for bank $i$ divided by the sum of the total asset of the banking system; $V R 3 M_{j t}=$ volatility of the three months interbank rate (standard deviation computed with daily data) for country $j ; L L P$ it $=$ loan loss provisions/net loans for bank $i$ at time $t ;$

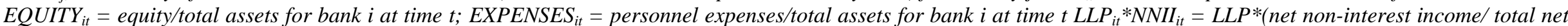
operating income) for bank $i$ at time $t ; L L P_{i t}^{*} C O M_{i t}=L L P *\left(\right.$ net commission and fee income/ total net operating income) for bank i at time $t$; $L L P_{i t} * T R A D_{i t}=L L P *($ net trading income/ total net operating income) for bank i at time $t$; $L L P_{i t}{ }^{*} C O M S H A_{i t}=L L P *(n e t$ commission and fee income/ net non-interest income). All the variables are expressed in \%. Therefore, the interacting variables are divided by 100 to obtain coefficients that can be directly compared to the coefficient of LLP. 


\section{References}

Angbazo, L., 1997. Commercial bank interest margins, default risk, interest-rate risk, and offbalance sheet banking. Journal of Banking and Finance 21(1), 55-87.

Baele, L., De Jonghe O., Vander Vennet, R., 2006. Does the stock market value bank diversification? Journal of Banking and Finance, forthcoming.

Boyd, J., Chang, C., Smith, D., 1998. Moral hazard under commercial and universal banking. Journal of Money, Credit and Banking 30(3).

Boyd, J., Graham, S., 1986. Risk, regulation, and bank holding company expansion. Federal Reserve Bank of Mineapolis, Quaterly Review, spring.

Boyd, J., Graham, G., Hewitt, R., 1993. Bank holding company mergers with nonblank financial firms, Journal of Banking and Finance 17, 43-63.

Boyd, J., Hanweck, G., Pithyachariyakul, P., 1980. Bank holding company diversification. Federal Reserve Bank of Chicago, Proceedings from a conference on Bank Structure and Competition, May, 105-120.

De Young, R., Roland, K., 2001. Product mix and earnings volatility at commercial banks: Evidence from a degree of total leverage model. Journal of Financial Intermediation 10, 5484.

Dingell, J., 2002. Letter to FRB and OCC re : "pay to play" practices, Jul 11. Available from www.house.gov/commerce democrats/press/1071tr179.htm.

Drakos, K., 2003. Assessing the success of reform in transition banking 10 years later: An interest margins analysis. Journal of Policy Modeling 25(3), 309-317.

European Central Bank, 2000. EU banks' income structure. Banking Supervision Committee, April.

Hausman, J., 1978. Specification Tests in Econometrics. Econometrica 46, 1251-1271.

Ho, T., Saunders, A., 1981. The determinants of bank interest margins : Theory and empirical evidence. Journal of Financial and Quantitative Analysis 16(4), 581-600.

John, K., John, T.A., Saunders A., 1994. Universal banking and firm risk-taking, Journal of Banking and Finance 18(2), 307-323.

Klein, M., 1971. A theory of the banking firm. Journal of Money, Credit and Banking 3(2), 205-218.

Kwan, S., 1998. Securities activities by commercial banking firms' section 20 subsidiaries: risk, return and diversification benefits. Economic Research, Federal Reserve Bank of San Francisco. 
Lepetit, L., Nys, E., Rous, P., Tarazi, A., 2006. Bank income structure and risk: An empirical analysis of European banks. Working paper, University of Limoges.

Maudos, J., De Guevara, J.F., 2004. Factors explaining the interest margin in the banking sectors of the European Union. Journal of Banking and Finance 28, 2259-2281.

Merton R.C., 1977. On the pricing of contingent claims and the Modigliani-Miller theorem. Journal of Financial Economics (5), 241-249.

Monti, M, 1972. Deposit, credit and interest rate determination under alternative bank objective functions. In: Karl Shell and Giorgio P. Szego, eds., Mathematical methods in investment and finance, North-Holland, Amsterdam, 430-454.

Puri, M., 1996. Conflicts of interest, intermediation, and the pricing of underwritten securities. Mimeo, Graduate School of Business, Stanford University, Mars.

Rajan, R., 1991. Conflict of interest and the separation of commercial and investment banking. Working Paper, University of Chicago.

Saunders, A., Schumacher, L., 2000. The determinants of bank interest margins: An international study. Journal of International Money and Finance 19(6), 813-832.

Smith, R., Staikouras, C., Wood, G., 2003. Non-interest income and total income stability.Working Paper n¹98- Bank of England.

Stiroh, K., 2004. Diversification in banking: Is non-interest income the answer? Journal of Money, Credit and Banking 36(5), 853-882.

Stiroh, K., Rumble, A., 2006. The dark side of diversification: The case of US financial holding companies. Journal of Banking and Finance 30(8), 2131-2161.

Wong, K.P., 1997. On the determinants of bank interest margins under credit and interest rate risks. Journal of Banking and Finance 21(2), 251-271. 
Appendix

Table A1. Distribution of banks by country

\begin{tabular}{lc}
\hline & Numbers of banks \\
\hline Austria & 3 \\
Belgium & 17 \\
Denmark & 42 \\
France & 149 \\
Italy & 152 \\
Netherlands & 24 \\
Norway & 15 \\
Portugal & 16 \\
Spain & 15 \\
Sweden & 6 \\
Switzerland & 106 \\
United Kingdom & 57 \\
\hline & Total \\
\hline \hline
\end{tabular}


Table A2. Cross section regression (OLS): impact of product diversification on net interest margin for European banks (1996)

\begin{tabular}{|c|c|c|c|c|c|c|c|c|c|c|c|}
\hline Equation & $\begin{array}{c}\mathrm{R} 3 \mathrm{M} \\
(+)\end{array}$ & $\begin{array}{l}\text { LLP } \\
(+)\end{array}$ & $\begin{array}{c}\text { LIQUIDITY } \\
(+)\end{array}$ & $\begin{array}{c}\text { EQUITY } \\
(+)\end{array}$ & $\begin{array}{c}\text { EXPENSES } \\
(+/-)\end{array}$ & $\begin{array}{c}\text { TA_R } \\
(+/-)\end{array}$ & $\begin{array}{c}\text { NNII } \\
(-)\end{array}$ & $\begin{array}{c}\text { COMSHA } \\
(-)\end{array}$ & $\begin{array}{c}\mathrm{COM} \\
(-)\end{array}$ & $\begin{array}{c}\text { TRAD } \\
(-)\end{array}$ & $\mathrm{R}^{2}$ \\
\hline \multicolumn{12}{|c|}{ Dependant variable: W_MARGIN (309 obs.) } \\
\hline$[1]$ & $\begin{array}{c}0.298 * * * \\
(9.237)\end{array}$ & $\begin{array}{c}0.074 \\
(0.813)\end{array}$ & $\begin{array}{c}-0.000 \\
(-0.170)\end{array}$ & $\begin{array}{c}-0.008 \\
(-0.486)\end{array}$ & $\begin{array}{c}0.614 * * * \\
(5.331)\end{array}$ & $\begin{array}{c}-6.537 * * * \\
(-3.174)\end{array}$ & - & - & - & - & 0.397 \\
\hline$[2]$ & $\begin{array}{c}0.178 * * * \\
(6.256)\end{array}$ & $\begin{array}{c}0.250 * * * \\
(3.554)\end{array}$ & $\begin{array}{c}0.000 \\
(0.168)\end{array}$ & $\begin{array}{c}0.001 \\
(0.056)\end{array}$ & $\begin{array}{c}0.966^{* * * *} \\
(9.359)\end{array}$ & $\begin{array}{l}-1.089 \\
(-0.629)\end{array}$ & $\begin{array}{c}-0.046 * * * \\
(-13.855)\end{array}$ & - & - & - & 0.682 \\
\hline$[3]$ & $\begin{array}{c}0.190 * * * \\
(6.279)\end{array}$ & $\begin{array}{c}0.234 * * * \\
(3.441)\end{array}$ & $\begin{array}{c}0.000 \\
(0.056)\end{array}$ & $\begin{array}{c}0.007 \\
(0.637)\end{array}$ & $\begin{array}{c}0.913 * * * \\
(8.891)\end{array}$ & $\begin{array}{c}-0.958 \\
(-0.562)\end{array}$ & $\begin{array}{c}-0.047 * * * \\
(-14.031)\end{array}$ & $\begin{array}{c}0.329 * * * \\
(4.739)\end{array}$ & - & - & 0.700 \\
\hline$[4]$ & $\begin{array}{c}0.160 * * * \\
(4.909)\end{array}$ & $\begin{array}{c}0.245^{* * *} * \\
(3.447)\end{array}$ & $\begin{array}{c}-0.000 \\
(-0.180)\end{array}$ & $\begin{array}{c}-0.001 \\
(-0.069)\end{array}$ & $\begin{array}{c}0.977 * * * \\
(8.336)\end{array}$ & $\begin{array}{c}-3.169 \\
(-1.637)\end{array}$ & - & - & $\begin{array}{c}-0.049 * * * \\
(-10.079)\end{array}$ & $\begin{array}{c}-0.035 * * * \\
(-4.434)\end{array}$ & 0.667 \\
\hline \multicolumn{12}{|c|}{ Dependant variable: $N \_M A R G I N$ (309 obs.) } \\
\hline$\left[1^{\prime}\right]$ & $\begin{array}{c}-0.097 \\
(-1.490)\end{array}$ & $\begin{array}{c}0.512 * * \\
(2.186)\end{array}$ & $\begin{array}{c}0.000 \\
(0.026)\end{array}$ & $\begin{array}{c}0.067 * * \\
(2.272)\end{array}$ & $\begin{array}{c}0.564 * * \\
(2.415)\end{array}$ & $\begin{array}{c}-4.535 \\
(-0.775)\end{array}$ & & & & & 0.127 \\
\hline$\left[2^{\prime}\right]$ & $\begin{array}{c}-0.084 \\
(-1.347)\end{array}$ & $\begin{array}{c}0.524 * * \\
(2.299)\end{array}$ & $\begin{array}{c}0.000 \\
(0.182)\end{array}$ & $\begin{array}{l}0.059^{*} \\
(1.932)\end{array}$ & $\begin{array}{l}0.477^{*} \\
(1.837)\end{array}$ & $\begin{array}{c}-6.393 \\
(-1.043)\end{array}$ & $\begin{array}{c}-0.012 \\
(-1.126)\end{array}$ & & & & 0.129 \\
\hline$\left[3^{\prime}\right]$ & $\begin{array}{c}-0.093 \\
(-1.473)\end{array}$ & $\begin{array}{c}0.521 * * \\
(2.281)\end{array}$ & $\begin{array}{c}0.000 \\
(0.141)\end{array}$ & $\begin{array}{l}0.059^{*} \\
(1.914)\end{array}$ & $\begin{array}{l}0.480^{*} \\
(1.858)\end{array}$ & $\begin{array}{l}-6.365 \\
(-1.028)\end{array}$ & $\begin{array}{c}-0.012 \\
(-1.091)\end{array}$ & $\begin{array}{c}-0.114 \\
(-0.478)\end{array}$ & & & 0.128 \\
\hline$\left[4^{\prime}\right]$ & $\begin{array}{c}0.170 * * \\
(2.285)\end{array}$ & $\begin{array}{c}0.587 * * \\
(2.152)\end{array}$ & $\begin{array}{c}-0.000 \\
(-0.463)\end{array}$ & $\begin{array}{c}0.092 * * * \\
(2.802)\end{array}$ & $\begin{array}{l}0.503^{*} \\
(1.670)\end{array}$ & $\begin{array}{c}-1.326 \\
(-0.313)\end{array}$ & & & $\begin{array}{c}0.012 \\
(0.818)\end{array}$ & $\begin{array}{c}0.054 \\
(0.999)\end{array}$ & 0.212 \\
\hline
\end{tabular}

Variable definitions: W_MARGIN = net interest income/total earning assets; $N$ _MARGIN = (interest from loans/net loans) - interest expenses/total liabiities ; LIQUIDITY

$=$ net loans/deposits; $T A R_{i t}=$ total assets for bank $i$ divided by the sum of the total asset of the banking system; $R 3 M_{j t}=$ the three months interbank rate; LLP $P_{i t}=$ loan loss provisions/net loans for bank i at time $t ; E_{\text {QUITY }}$ = equity/total assets for bank i at time $t$; EXPENSES ${ }_{i t}=$ personnel expenses/total assets for bank i at time $t$; NNII $_{i t}=$ net non-interest income/ total net operating income for bank $i$ at time $t ; C_{i t}=$ net commission and fee income/ total net operating income for bank i at time $t ;$ TRAD $_{i t}=$ net trading income/ total net operating income for bank $i$ at time $t ;$ COMSHA $_{i t}=$ net commission and fee income/ net non-interest income. 
Table A3. Cross section regression (OLS): impact of product diversification on risk premium for European banks (1996)

\begin{tabular}{|c|c|c|c|c|c|c|c|c|c|c|}
\hline Equation & $\begin{array}{c}\text { VR3M } \\
(+)\end{array}$ & $\begin{array}{l}\text { LLP } \\
(+)\end{array}$ & $\begin{array}{c}\text { EQUITY } \\
(+)\end{array}$ & $\begin{array}{c}\text { EXPENSES } \\
(+/-)\end{array}$ & $\begin{array}{c}\text { TA_R } \\
(+/-)\end{array}$ & $\begin{array}{l}\text { NNII } \\
(-)\end{array}$ & $\begin{array}{c}\text { COMSHA } \\
(-)\end{array}$ & $\begin{array}{c}\mathrm{COM} \\
(-)\end{array}$ & $\begin{array}{c}\text { TRAD } \\
(-)\end{array}$ & $\mathrm{R}^{2}$ \\
\hline \multicolumn{11}{|c|}{ Dependant variable: W_SPREAD (309 obs.) } \\
\hline [5] & $\begin{array}{c}1.605 * * * \\
(4.578)\end{array}$ & $\begin{array}{c}0.103 \\
(0.884)\end{array}$ & $\begin{array}{l}-0.041 \\
(-1.114)\end{array}$ & $\begin{array}{l}0.392^{*} \\
(1.671)\end{array}$ & $\begin{array}{c}-12.773 * * \\
(-2.489)\end{array}$ & 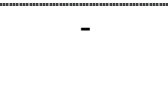 & - & - & - & 0.116 \\
\hline$[6]$ & $\begin{array}{c}0.376 \\
(0.939)\end{array}$ & $\begin{array}{c}0.359 * * * \\
(3.156)\end{array}$ & $\begin{array}{c}-0.021 \\
(-0.750)\end{array}$ & $\begin{array}{c}0.863 * * * \\
(3.698)\end{array}$ & $\begin{array}{c}0.131 \\
(0.041)\end{array}$ & $\begin{array}{c}-0.056 * * * \\
(-6.314)\end{array}$ & - & - & - & 0.362 \\
\hline [7] & $\begin{array}{c}0.502 \\
(1.408)\end{array}$ & $\begin{array}{c}0.313 * * * \\
(3.059)\end{array}$ & $\begin{array}{c}-0.007 \\
(-0.329)\end{array}$ & $\begin{array}{c}0.745 * * * \\
(4.708)\end{array}$ & $\begin{array}{c}-0.065 \\
(-0.022)\end{array}$ & $\begin{array}{c}-0.058 * * * \\
(-7.407)\end{array}$ & $\begin{array}{c}0.791 * * \\
(2.580)\end{array}$ & - & - & 0.425 \\
\hline [8] & $\begin{array}{c}0.174 \\
(0.401)\end{array}$ & $\begin{array}{c}0.335^{* * *} * \\
(2.982)\end{array}$ & $\begin{array}{c}-0.027 \\
(-0.852)\end{array}$ & $\begin{array}{c}0.869 * * * \\
(3.519)\end{array}$ & $\begin{array}{c}-3.259 \\
(-0.957)\end{array}$ & & - & $\begin{array}{c}-0.062 * * * \\
(-6.444)\end{array}$ & $\begin{array}{c}-0.019 \\
(-1.248)\end{array}$ & 0.309 \\
\hline \multicolumn{11}{|c|}{ Dependant variable: N_SPREAD (309 obs.) } \\
\hline [5'] & $\begin{array}{c}-0.527 \\
(-1.403)\end{array}$ & $\begin{array}{c}0.442 * * \\
(2.101)\end{array}$ & $\begin{array}{c}0.081 * * \\
(2.593)\end{array}$ & $\begin{array}{c}0.464 * * \\
(2.489)\end{array}$ & $\begin{array}{l}-9.409^{*} \\
(-1.716)\end{array}$ & - & - & - & - & 0.120 \\
\hline$\left[6^{\prime}\right]$ & $\begin{array}{c}-0.511 \\
(-1.352)\end{array}$ & $\begin{array}{c}0.455^{* *} \\
(2.147)\end{array}$ & $\begin{array}{c}0.078 * * \\
(2.460)\end{array}$ & $\begin{array}{c}0.428 * * \\
(2.084)\end{array}$ & $\begin{array}{r}-10.195^{*} \\
(-1.697)\end{array}$ & $\begin{array}{c}0.004 \\
(0.416)\end{array}$ & - & - & - & 0.119 \\
\hline [7'] & $\begin{array}{c}-0.515 \\
(-1.342)\end{array}$ & $\begin{array}{c}0.454 * * \\
(2.141)\end{array}$ & $\begin{array}{c}0.078 * * \\
(2.459)\end{array}$ & $\begin{array}{c}0.427 * * \\
(2.061)\end{array}$ & $\begin{array}{c}-10.192^{*} \\
(-1.696)\end{array}$ & $\begin{array}{c}0.004 \\
(0.398)\end{array}$ & $\begin{array}{c}0.007 \\
(0.030)\end{array}$ & - & - & 0.118 \\
\hline$\left[8^{\prime}\right]$ & $\begin{array}{c}1.574 * * * \\
(3.169)\end{array}$ & $\begin{array}{l}0.428^{*} \\
(1.741) \\
\end{array}$ & $\begin{array}{c}0.104^{* * * *} \\
(3.099)\end{array}$ & $\begin{array}{l}0.426^{*} \\
(1.830) \\
\end{array}$ & $\begin{array}{c}-6.333 \\
(-1.067) \\
\end{array}$ & - & - & $\begin{array}{c}0.005 \\
(0.354) \\
\end{array}$ & $\begin{array}{c}0.051 * * * \\
(3.499) \\
\end{array}$ & 0.206 \\
\hline
\end{tabular}

Variable definitions: W SPREAD = the ratio of net interest income to total earning assets - the 10 year government bond rate; $N$ SPREAD = lending rate determined as the ratio of interest from loans to net loans - the 10 year government bond rate; TA_ $R_{i t}=$ total assets for bank $i$ divided by the sum of the total asset of the banking system; $V R 3 M_{j t}=$ volatility of the three months interbank rate (standard deviation computed with daily data) for country $j ;$ LLP it $=$ loan loss provisions/net loans for bank $i$ at time $t ;$

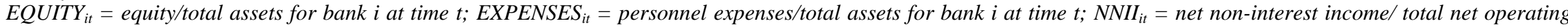
income for bank $i$ at time $t$; $C O M_{i t}=$ net commission and fee income/ total net operating income for bank $i$ at time $t$; TRAD for bank i at time $t$; COMSHA ${ }_{\text {it }}=$ net commission and fee income/ net non-interest income. 
Table A4. Cross section regression (OLS): impact of product diversification on net interest margin for European banks (2002)

\begin{tabular}{|c|c|c|c|c|c|c|c|c|c|c|c|}
\hline Equation & $\begin{array}{c}\text { R3M } \\
(+)\end{array}$ & $\begin{array}{r}\text { LLP } \\
(+)\end{array}$ & $\begin{array}{c}\text { LIQUIDITY } \\
(+)\end{array}$ & $\begin{array}{c}\text { EQUITY } \\
(+)\end{array}$ & $\begin{array}{c}\text { EXPENSES } \\
(+/-)\end{array}$ & $\begin{array}{c}\text { TA_R } \\
(+/-)\end{array}$ & $\begin{array}{c}\text { NNII } \\
(-)\end{array}$ & $\begin{array}{c}\text { COMSHA } \\
(-)\end{array}$ & $\begin{array}{c}\mathrm{COM} \\
(-)\end{array}$ & $\begin{array}{c}\text { TRAD } \\
(-)\end{array}$ & $\mathrm{R}^{2}$ \\
\hline \multicolumn{12}{|c|}{ Dependant variable: W_MARGIN (299 obs.) } \\
\hline$[1]$ & $\begin{array}{c}0.266^{* * * *} \\
(7.543)\end{array}$ & $\begin{array}{l}0.160^{*} \\
(1.774)\end{array}$ & $\begin{array}{c}0.000 \\
(0.045)\end{array}$ & $\begin{array}{c}0.011 \\
(1.004)\end{array}$ & $\begin{array}{l}0.189^{*} \\
(1.897)\end{array}$ & $\begin{array}{c}-5.440 * * * \\
(-4.518)\end{array}$ & - & - & - & - & 0.186 \\
\hline$[2]$ & $\begin{array}{c}0.211 * * * \\
(5.914)\end{array}$ & $\begin{array}{c}0.147 * * \\
(2.347)\end{array}$ & $\begin{array}{c}-0.000 \\
(-0.100)\end{array}$ & $\begin{array}{c}0.009 \\
(0.883)\end{array}$ & $\begin{array}{c}0.466^{* * *} \\
(3.776)\end{array}$ & $\begin{array}{c}-2.897 * * * \\
(-3.124)\end{array}$ & $\begin{array}{c}-0.029 * * * \\
(-12.324)\end{array}$ & - & - & - & 0.471 \\
\hline$[3]$ & $\begin{array}{c}0.214 * * * \\
(6.192)\end{array}$ & $\begin{array}{c}0.147 * * \\
(2.341)\end{array}$ & $\begin{array}{c}-0.000 \\
(-0.116)\end{array}$ & $\begin{array}{c}0.009 \\
(0.941)\end{array}$ & $\begin{array}{c}0.469 * * * \\
(3.761)\end{array}$ & $\begin{array}{c}-2.984 * * * \\
(-3.156)\end{array}$ & $\begin{array}{c}-0.030 * * * \\
(-10.840)\end{array}$ & $\begin{array}{c}-0.073 \\
(-0.654)\end{array}$ & - & - & 0.473 \\
\hline$[4]$ & $\begin{array}{c}0.205^{* * *} \\
(5.948)\end{array}$ & $\begin{array}{l}0.142 * * \\
(2.329)\end{array}$ & $\begin{array}{c}-0.000 \\
(-0.229)\end{array}$ & $\begin{array}{c}0.012 \\
(1.232)\end{array}$ & $\begin{array}{c}0.468 * * * \\
(3.477)\end{array}$ & $\begin{array}{c}-3.557 * * * \\
(-4.046)\end{array}$ & - & - & $\begin{array}{c}-0.030 * * * \\
(-7.254)\end{array}$ & $\begin{array}{c}-0.033 * * * \\
(-9.666)\end{array}$ & 0.493 \\
\hline \multicolumn{12}{|c|}{ Dependant variable: $N \_M A R G I N$ (299 obs.) } \\
\hline$\left[1^{\prime}\right]$ & $\begin{array}{c}-0.071 \\
(-0.690)\end{array}$ & $\begin{array}{c}0.924 * * * \\
(5.508)\end{array}$ & $\begin{array}{c}0.000 \\
(0.608)\end{array}$ & $\begin{array}{c}0.007 \\
(0.375)\end{array}$ & $\begin{array}{l}0.312^{* *} \\
(2.412)\end{array}$ & $\begin{array}{c}-8.154 * * * \\
(-3.972)\end{array}$ & - & - & - & - & 0.127 \\
\hline$\left[2^{\prime}\right]$ & $\begin{array}{c}-0.065 \\
(-0.635)\end{array}$ & $\begin{array}{c}0.904 * * * \\
(5.334)\end{array}$ & $\begin{array}{c}0.000 \\
(0.700)\end{array}$ & $\begin{array}{c}0.004 \\
(0.214)\end{array}$ & $\begin{array}{l}0.277^{*} \\
(1.722)\end{array}$ & $\begin{array}{c}-8.545 * * * \\
(-3.832)\end{array}$ & $\begin{array}{c}-0.004 \\
(-0.452)\end{array}$ & - & - & - & 0.122 \\
\hline$\left[3^{\prime}\right]$ & $\begin{array}{c}-0.057 \\
(-0.556)\end{array}$ & $\begin{array}{c}0.894 * * * \\
(5.277)\end{array}$ & $\begin{array}{l}-0.000 \\
(-0.226)\end{array}$ & $\begin{array}{c}0.004 \\
(0.229)\end{array}$ & $\begin{array}{l}0.285^{*} \\
(1.751)\end{array}$ & $\begin{array}{c}-8.682 * * * \\
(-3.846)\end{array}$ & $\begin{array}{c}-0.004 \\
(-0.410)\end{array}$ & $\begin{array}{c}-0.216 \\
(-1.097)\end{array}$ & - & - & 0.123 \\
\hline$\left[4^{\prime}\right]$ & $\begin{array}{c}-0.019 \\
(-0.194)\end{array}$ & $\begin{array}{c}0.995 * * * \\
(4.537)\end{array}$ & $\begin{array}{c}-0.000 \\
(-1.436)\end{array}$ & $\begin{array}{c}0.022 \\
(1.128)\end{array}$ & $\begin{array}{c}0.506^{* *} \\
(2.734)\end{array}$ & $\begin{array}{c}-3.397 * * \\
(-2.103)\end{array}$ & - & - & $\begin{array}{c}-0.024 * * \\
(-2.509)\end{array}$ & $\begin{array}{c}0.000 \\
(0.011)\end{array}$ & 0.215 \\
\hline
\end{tabular}

Variable definitions: W MARGIN = net interest income/total earning assets; $N$ MARGIN = (interest from loans/net loans) - interest expenses/total liabiities ; LIQUIDITY

$=$ net loans/deposits; $T A R_{i t}=$ total assets for bank $i$ divided by the sum of the total asset of the banking system; $R 3 M_{j t}=$ the three months interbank rate; LLP $P_{i t}=$ loan loss provisions/net loans for bank i at time $t ; E_{\text {QUITY }}$ = equity/total assets for bank i at time $t$; EXPENSES ${ }_{i t}=$ personnel expenses/total assets for bank i at time $t$; NNII $_{i t}=$ net non-interest income/ total net operating income for bank $i$ at time $t ; C_{i t}=$ net commission and fee income/ total net operating income for bank i at time $t ;$ TRAD $_{i t}=$ net trading income/ total net operating income for bank $i$ at time $t ;$ COMSHA $_{i t}=$ net commission and fee income/ net non-interest income. 
Table A5. Cross section regression (OLS): impact of product diversification on risk premium for European banks (2002)

\begin{tabular}{|c|c|c|c|c|c|c|c|c|c|c|}
\hline Equation & $\begin{array}{c}\text { VR3M } \\
(+)\end{array}$ & $\begin{array}{l}\text { LLP } \\
(+)\end{array}$ & $\begin{array}{c}\text { EQUITY } \\
(+)\end{array}$ & $\begin{array}{c}\text { EXPENSES } \\
(+/-)\end{array}$ & $\begin{array}{c}\text { TA_R } \\
(+/-)\end{array}$ & $\begin{array}{l}\text { NNII } \\
(-)\end{array}$ & $\begin{array}{c}\text { COMSHA } \\
(-)\end{array}$ & $\begin{array}{c}\mathrm{COM} \\
(-)\end{array}$ & $\begin{array}{c}\text { TRAD } \\
(-)\end{array}$ & $\mathrm{R}^{2}$ \\
\hline \multicolumn{11}{|c|}{ Dependant variable: W_SPREAD (309 obs.) } \\
\hline [5] & $\begin{array}{c}2.712^{* * *} \\
(2.992)\end{array}$ & $\begin{array}{l}-0.023 \\
(-0.147)\end{array}$ & $\begin{array}{c}0.005 \\
(0.141)\end{array}$ & $\begin{array}{c}-0.089 \\
(-1.354)\end{array}$ & $\begin{array}{l}-1.485 \\
(-1.22)\end{array}$ & 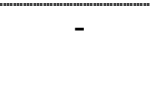 & - & - & - & 0.054 \\
\hline$[6]$ & $\begin{array}{c}2.834 * * * \\
(3.220)\end{array}$ & $\begin{array}{c}-0.010 \\
(-0.067)\end{array}$ & $\begin{array}{c}0.011 \\
(0.258)\end{array}$ & $\begin{array}{c}-0.028 \\
(-0.147)\end{array}$ & $\begin{array}{c}-0.497 \\
(-0.388)\end{array}$ & $\begin{array}{c}-0.014 * * \\
(-2.319)\end{array}$ & - & - & - & 0.083 \\
\hline$[7]$ & $\begin{array}{c}2.928 * * * \\
(3.364)\end{array}$ & $\begin{array}{c}-0.009 \\
(-0.062)\end{array}$ & $\begin{array}{c}0.012 \\
(0.267)\end{array}$ & $\begin{array}{c}-0.016 \\
(-0.084)\end{array}$ & $\begin{array}{c}-0.628 \\
(-0.496)\end{array}$ & $\begin{array}{c}-0.015^{* *} * \\
(-2.460)\end{array}$ & $\begin{array}{c}-0.201 \\
(-1.364)\end{array}$ & - & - & 0.089 \\
\hline$[8]$ & $\begin{array}{c}3.126^{* * *} \\
(3.621)\end{array}$ & $\begin{array}{c}0.009 \\
(0.058)\end{array}$ & $\begin{array}{c}0.017 \\
(0.462)\end{array}$ & $\begin{array}{c}-0.035 \\
(-0.577)\end{array}$ & $\begin{array}{c}-1.051 \\
(-0.856)\end{array}$ & & - & $\begin{array}{c}-0.022 * * * \\
(-3.357)\end{array}$ & $\begin{array}{c}-0.003 \\
(-0.391)\end{array}$ & 0.113 \\
\hline \multicolumn{11}{|c|}{ Dependant variable: N_SPREAD (309 obs.) } \\
\hline$\left[5^{\prime}\right]$ & $\begin{array}{c}5.061 * * * \\
(3.661)\end{array}$ & $\begin{array}{c}0.945^{* * *} \\
(6.457)\end{array}$ & $\begin{array}{c}0.004 \\
(0.249)\end{array}$ & $\begin{array}{c}0.021 \\
(0.278)\end{array}$ & $\begin{array}{c}-9.381 * * * \\
(-4.470)\end{array}$ & - & - & - & - & 0.120 \\
\hline [6’] & $\begin{array}{c}4.946 * * * \\
(3.673)\end{array}$ & $\begin{array}{c}0.946 * * * \\
(6.238)\end{array}$ & $\begin{array}{c}0.003 \\
(0.182)\end{array}$ & $\begin{array}{c}-0.005 \\
(-0.033)\end{array}$ & $\begin{array}{c}-9.504 * * * \\
(-4.222)\end{array}$ & $\begin{array}{c}0.005 \\
(0.540)\end{array}$ & - & - & - & 0.119 \\
\hline$\left[7^{\prime}\right]$ & $\begin{array}{c}5.210 * * * \\
(3.874)\end{array}$ & $\begin{array}{c}0.929 * * * \\
(6.166)\end{array}$ & $\begin{array}{c}0.003 \\
(0.147)\end{array}$ & $\begin{array}{c}0.014 \\
(0.086)\end{array}$ & $\begin{array}{c}-9.812 * * * \\
(-4.298)\end{array}$ & $\begin{array}{c}0.004 \\
(0.400)\end{array}$ & $\begin{array}{c}-0.573 * * * \\
(-3.458)\end{array}$ & - & - & 0.118 \\
\hline$\left[8^{\prime}\right]$ & $\begin{array}{c}5.977 * * * \\
(4.707)\end{array}$ & $\begin{array}{c}0.875^{* * * *} \\
(4.704)\end{array}$ & $\begin{array}{c}0.032 \\
(1.565) \\
\end{array}$ & $\begin{array}{c}0.027 \\
(0.371) \\
\end{array}$ & $\begin{array}{c}-3.313 * * \\
(-2.281)\end{array}$ & - & - & $\begin{array}{c}0.007 \\
(0.691) \\
\end{array}$ & $\begin{array}{c}-0.014 \\
(-1.139) \\
\end{array}$ & 0.206 \\
\hline
\end{tabular}

Variable definitions: W SPREAD = the ratio of net interest income to total earning assets - the 10 year government bond rate; $N$ SPREAD = lending rate determined as the ratio of interest from loans to net loans - the 10 year government bond rate; TA_ $R_{i t}=$ total assets for bank $i$ divided by the sum of the total asset of the banking system; $V R 3 M_{i t}=$ volatility of the three months interbank rate (standard deviation computed with daily data) for country $j ;$ LLP

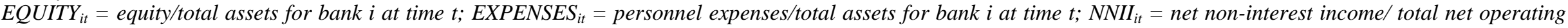
income for bank $i$ at time $t$; $C O M_{i t}=$ net commission and fee income/ total net operating income for bank $i$ at time $t$; TRA $D_{i t}=n e t$ trading income/ total net operating income for bank i at time $t$; COMSHA ${ }_{i t}=$ net commission and fee income/ net non-interest income. 
Table A6. Descriptive statistics for large and small European commercial and cooperative banks, on average over the period $1996-2002$

\begin{tabular}{|c|c|c|c|c|c|c|c|c|c|c|c|c|c|c|c|c|}
\hline & LOANS & DEP & EQUITY & LLP & EXPENSES & ROA & ROE & W_MARGIN & N_MARGIN & W_SPREAD & N_SPREAD & NII & NNII & $\mathrm{COM}$ & TRAD & TA \\
\hline \multicolumn{17}{|c|}{ Large banks, TA>1 billion euros (359 banks) } \\
\hline Mean & 59.41 & 51.53 & 6.70 & 0.68 & 1.51 & 0.64 & 9.93 & 2.64 & -0.25 & 1.39 & 0.72 & 63.38 & 36.62 & 28.31 & 6.21 & 30857 \\
\hline Max & 95.93 & 91.89 & 36.50 & 6.77 & 21.48 & 5.06 & 68.99 & 8.75 & 12.21 & 11.69 & 24.12 & 100 & 99.96 & 78.32 & 78.35 & 745000 \\
\hline Min & 11.57 & 0.75 & 0.42 & -2.02 & 0.07 & -2.66 & -138.88 & 0 & -23.42 & -4.07 & -5.24 & 0.03 & 0 & -18.31 & -46.06 & 1000 \\
\hline Std & 17.06 & 16.91 & 3.07 & 0.66 & 0.93 & 0.55 & 10.05 & 1.12 & 4.62 & 1.64 & 3.00 & 16.08 & 16.08 & 12.86 & 8.80 & 87755 \\
\hline \multicolumn{17}{|c|}{ Small Banks, $T A<1$ billion euros (243 banks) } \\
\hline Mean & 62.30 & 53.68 & 11.89 & 0.68 & 1.79 & 1.02 & 8.29 & 3.02 & 2.79 & 1.43 & 2.43 & 68.38 & 31.62 & 25.35 & 5.82 & 450 \\
\hline Max & 95.78 & 88.25 & 53.43 & 9.29 & 10.60 & 16.08 & 64.84 & 10.42 & 18.18 & 16.16 & 25.83 & 100 & 95.68 & 96.77 & 65.22 & 999 \\
\hline Min & 5.69 & 8.30 & 5.82 & -2.02 & 0.24 & -14.87 & -175.77 & 0.45 & -17.66 & -4.15 & -5.35 & 4.32 & 0 & -14.68 & -70.80 & 17 \\
\hline Std & 17.87 & 13.81 & 7.35 & 0.82 & 1.32 & 1.41 & 10.16 & 1.29 & 3.71 & 1.84 & 2.89 & 22.08 & 22.08 & 19.06 & 8.56 & 248 \\
\hline
\end{tabular}

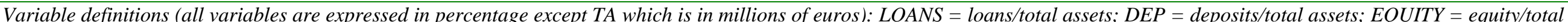

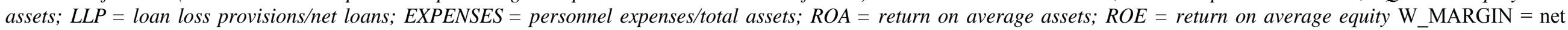

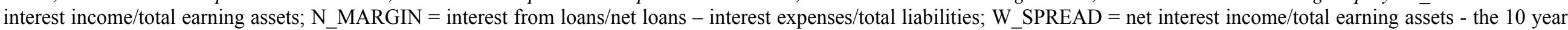

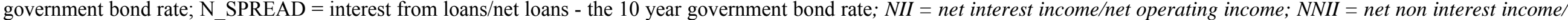
net operating income; $C \bar{O} M=$ net commission income/net operating income; TRAD = net trading income/net operating income; TA : total assets in millions of euros. 